\title{
MAPEAMENTO DE SOLOS E DE PRODUTIVIDADE EM PLANTAÇÕES DE Eucalyptus grandis NA ESTAÇÃO EXPERIMENTAL DE ITATINGA, ESALQ, COM USO DE GEOPROCESSAMENTO
}

\section{THAIS DIAS GONÇALVES}

Bacharel em Geografia

Orientador: Prof. Dr. JOSÉ LEONARDO DE MORAES GONÇALVES

Dissertação apresentada à Escola Superior de Agricultura "Luiz de Queiroz", Universidade de São Paulo, para obtenção do título de Mestre em Recursos Florestais, com opção em Manejo de Florestas de Produção.

PIRACICABA

Estado de São Paulo - Brasil

Abril -2003 


\section{Dados Internacionais de Catalogação na Publicação (CIP) DIVISÃO DE BIBLIOTECA E DOCUMENTAÇ̃̃OO - ESALQ/USP}

Gonçalves, Thais Dias

Mapeamento de solos e de produtividade em plantações de Eucalyptus grandis na Estação Experimental de Itatlnga, ESALQ, com uso de geoprocessamento / Thais Dias Gonçalves. - - Piracicaba, 2003.

$47 p$.

Dissertação (mestrado) - • Escola Superior de Agricultura Luiz de Queiroz, 2003.

Bibliografia.

1. Classificação do solo 2. Eucalipto 3. Geografia fisica 4. Geoprocessamento 5. Manejo florestal 6. Mapa pedológico 7. Mapeamento do solo 1 Título

CD 634.9734 
Aos meus pais, Paulo e Izabel, que como amigos, educadores e provedores proporcionaram-me 0 maior de todos os bens: o conhecimento.

Aos meus irmãos, Ou e Paulinha, pelo amor incondicional que só a família oferece.

Ao meu amor, Cacá, que nesses dois anos mudou minha vida ... tornando-me uma pessoa melhor e mais feliz, 


\section{AGRADECIMENTOS}

- Prof. Dr. José Leonardo de Moraes Gonçalves pelo entusiasmo com que conduziu a orientação deste trabalho e pela confiança que teve em mim para executá-lo;

- Prof. Dr. Carlos Alberto Vettorazzi, também, pela orientação, pelas sugestões sempre válidas e pela oportunidade de trabalharmos juntos na monitoria da disciplina Sistemas de Informação Geográfica;

- Prof. Dr. José Flávio Morais Castro, pela orientação desde os tempos da graduação, pela amizade, e pela disponibilidade de ajudar, sempre que precisei;

- Prof. Dr. Rubens Ângulo Filho e Prof. Dr. Antônio Natal Gonçalves pelas críticas e sugestões apresentadas no exame geral de qualificação;

- Aos amigos do Viveiro de Mudas do LCF: Amarildo, que sempre me ajudou a resolver os problemas logísticos do trabalho; Ivan, pela ajuda inestimável nos trabalhos de campo; PC, pela ajuda e orientação no campo e redação da dissertação; além do Arthur, do Chico, do Jarede, e da Luciane;

- Aos funcionários da Estação Experimental de Ciências Florestais de Itatinga, pela hospitalidade, eficiência e amizade, em especial: Rildo, Elaine, Lourival e D. Lena (pela comidinha maravilhosa);

- A Cia Suzano de Papel e Celusose S/A, em especial o engenheiro José Luiz Gava pela disponibilidade de dados inventário florestal e análise foliar dos plantios e pelo livre acesso a área;

- Aos funcionários do IPEF e LCF pela ajuda e boa vontade sempre, em especial, Ivo, Evandro, Rogério, Margareth e Alexandre;

- A agência financiadora CAPES - Coordenação de Aperfeiçamento de Pessoal de Nível Superior, pelas bolsas de Mestrado e do Programa PAE concedidas;

- Aos amigos que fiz em Piracicaba e que contribuíram para fazerem esta etapa menos árdua e mais divertida: Robertinha e Vitor, PC e Cleci, Gustavo e Grazi João e Miriam, e Bebei;

- Ao meu amigo Rogério Dell'Antonio pelo auxílio na parte de geoprocessamento;

- A minha companheira de casa e acima de tudo amiga: Eva. 


\section{SUMÁRIO}

Página

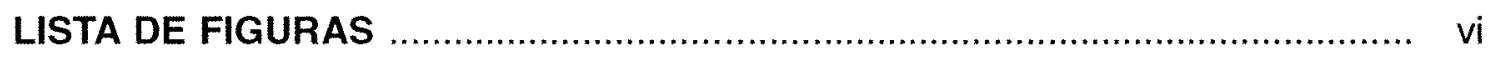

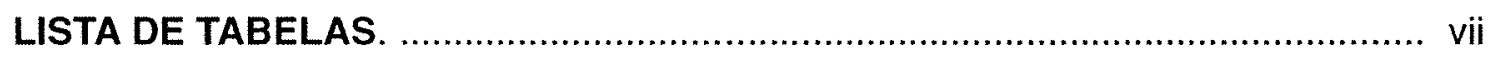

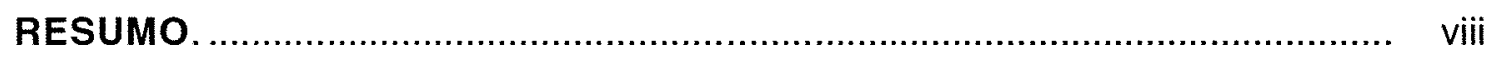

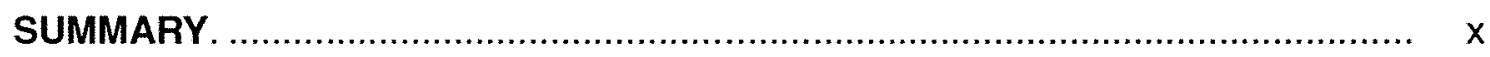

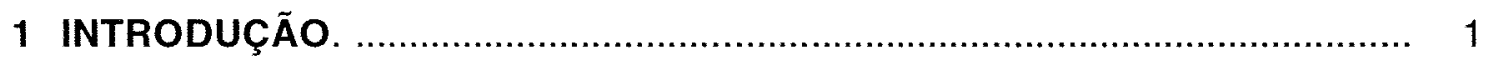

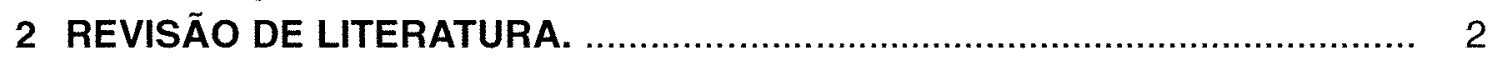

2.1 Estimação da produtividade florestal .................................................. 2

Método direto .................................................................................... 3

Método indireto. ...................................................................................... 4

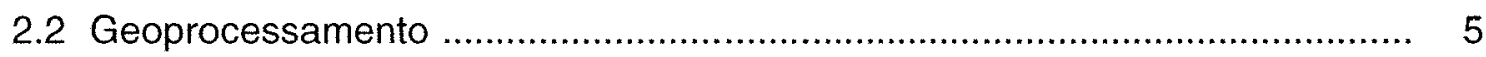

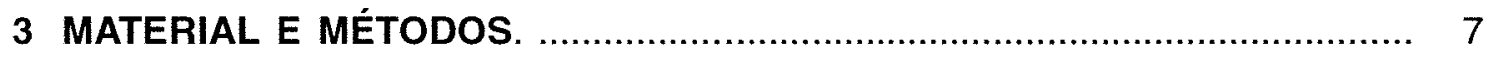

3.1 Caracterização da área experimental .................................................... 7

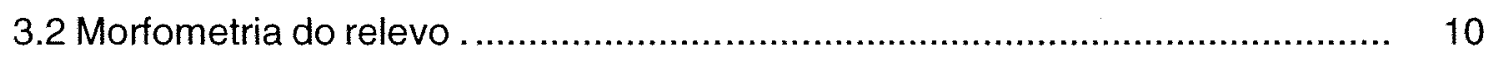

3.3 Mapa detalhado de solos ................................................................ 13

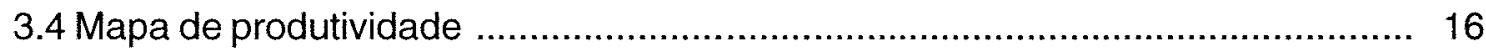

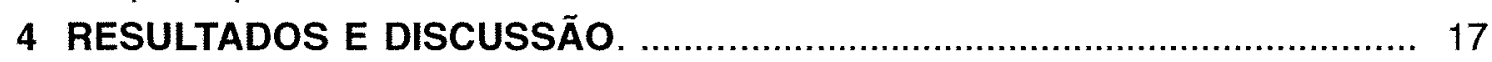

4.1 Morfometria do relevo ........................................................................ 17

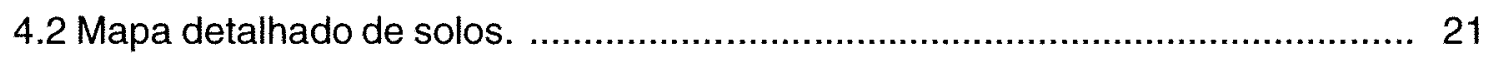

Descrição dos solos. ............................................................................... 22

Latossolo Vermelho-Amarelo Distrófico típico A moderado

textura média. ................................................................................... 22

Latossolo Vermelho Distrófico típico A moderado textura

argilosa e média. ............................................................................... 26

Latossolo Distroférrico típico A moderado textura argilosa . ..................... 26

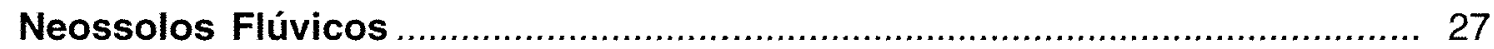

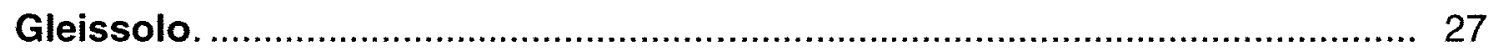

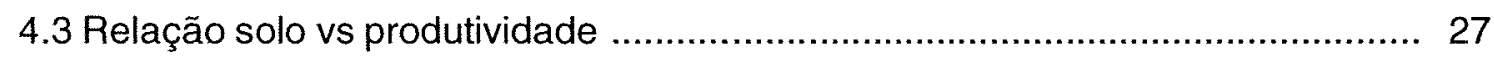

5 CONCLUSOES. .......................................................................... 36

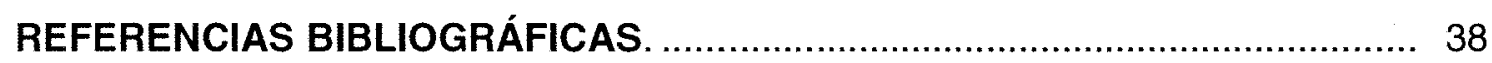




\section{LISTA DE FIGURAS}

Página

$1 \quad$ Mapa de localização da Estação Experimental de Itatinga ................................. 7

2 Média da variação anual de precipitação e de temperatura máximas e

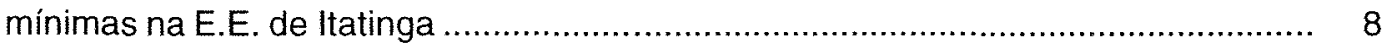

3 (a) Área atualmente preservada e (b) área que deve ser legalmente

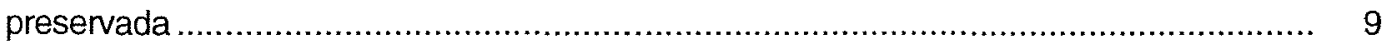

4 Mapa de articulação das cartas topográficas na E.E. de Itatinga ........................... 11

$5 \quad$ Mapa de divisão da E.E. de Itatinga ............................................................. 12

$6 \quad$ Mapa planialtimétrico da E.E. de Itatinga .................................................. 18

$7 \quad$ Mapa de classes de altitude da E.E. de Itatinga ................................................. 19

8 Mapa de classes de declividade da E.E. de Itatinga ........................................... 20

$9 \quad$ Mapa geológico (IPT,1984) da E.E. de Itatinga ................................................ 28

10 Mapa detalhado de solos da E.E. de Itatinga .............................................. 29

11 Classes de produtividade, baseadas no IMA …............................................. 30

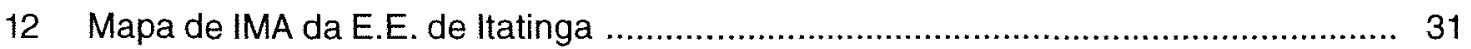

13 Relação entre produtividade observada e estimada na camada $0-20 \mathrm{~cm}$

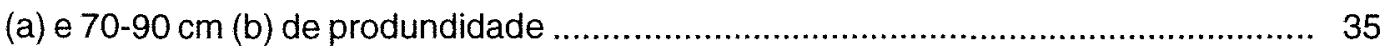




\section{LISTA DE TABELAS}

Página

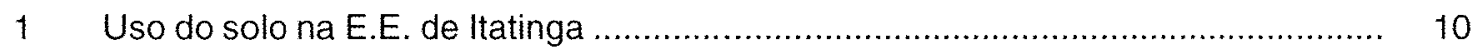

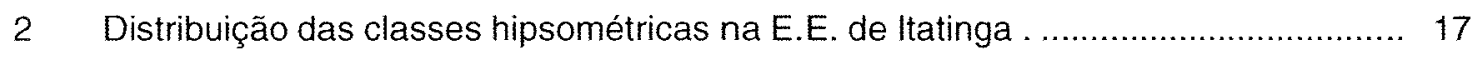

3 Distribuição das classes de declividade na E.E. de Itatinga .............................. 21

4 Classificação taxonômica dos solos da E.E. de Itatinga ....................................... 22

5 Descrição morfológica dos latossolos na E.E. de Itatinga ................................... 23

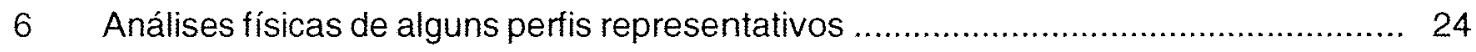

$7 \quad$ Análises químicas de alguns perfis representativos .................................... 25

8 Matriz de correlação ( $r$ ) entre variáveis nas camadas $0-20$ e $70-90 \mathrm{~cm}$

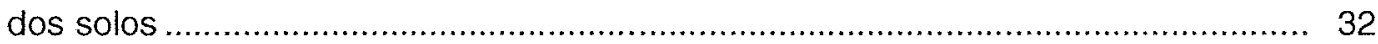

9 Valores mínimos, máximos, médios e desvios padrões de algumas características físicas e químicas dos diferentes solos ..................................... 33

10 Equação de regressão múltipla relacionando o IMA com características do solo 


\title{
MAPEAMENTO DE SOLOS E DE PRODUTIVIDADE EM PLANTAÇÕES DE Eucalyptus grandis NA ESTAÇÃO EXPERIMENTAL DE ITATINGA, ESALQ, COM USO DE GEOPROCESSAMENTO
}

\author{
Autora: THAIS DIAS GONÇALVES \\ Orientador: Prof. Dr. JOSÉ LEONARDO DE MORAES GONÇALVES
}

\section{RESUMO}

Este trabalho teve como objetivos fazer a caracterização fisiográfica, complementar o levantamento pedológico, fazer o mapeamento da produtividade de plantações de eucalipto e identificar relações entre produtividade florestal e características edáficas na Estação Experimental de Itatinga (ESALQ/USP), com uso de técnicas de levantamento de campo, análises laboratoriais e geoprocessamento. Para a estruturação da base cartográfica digital, como fonte primária de dados, foram usadas imagens de satélite, fotografias aéreas e levantamentos de campo e, como fonte secundária, cartas topográficas, mapa pedológico, mapa geológico e mapa de uso e ocupação do solo. $\mathrm{O}$ mapa planialtimétrico analógico foi obtido a partir de cartas topográficas em escala 1:10.000, elaboradas pelo Instituto Geográfico e Cartográfico do Estado de São Paulo IGC. A partir das imagens scanerizadas (raster) utilizou-se o software AutoCAD R14 para a digitalização "heads-up" (vetorização). A partir do mapa planialtimétrico, gerado no software AutoCAD R14, o arquivo digitalizado foi convertido do formato DXF para DAT, com uso do software DXF3DAT e em seguida a grade regular foi exportada para o software Idrisi for Windows 2.0. No Idrisi foram gerados os mapas hipsométrico e de declividade, o que possibilitou separar em classes a altitude e declividade, utilizando a rotina "reclass". Com uso do mapa pedológico detalhado de parte da E.E. de Itatinga; do mapa 
planialtimétrico; de prospecções de campo e de caracterizações dos solos da área nãomapeada, elaborou-se o mapa pedológico detalhado de toda a propriedade. Para o mapeamento da produtividade, foram usados dados de inventário de parcelas permanentes (mesma espécie, procedência e idade) obtidos em plantações Eucalyptus grandis conduzidas entre 1991 a 1997. Para a definição das classes de produtividade, escolheuse como indicador da produtividade o Incremento Médio Anual (IMA) do volume sólido de madeira com casca, pois foi o que apresentou maiores correlações com as características edáficas. Por meio de análise de correlação simples e de análises de regressão múltipla, tipo stepwise, modelo backward, a variável dependente, IMA dos povoamentos de $E$. grandis foram relacionadas com algumas características físicas e químicas dos solos. Foram identificados dois padrões de curvas de nível, um com curvas próximas, estreitas e circundantes à rede de drenagem, nas áreas mais íngremes e de menor altitude; outro, com curvas espaçadas, presentes nas áreas de maior altitude e com relevo plano e suave ondulado. Estreitamente relacionadas com os padrões fisiográficos, foram caracterizados cinco classes de solo. Foram encontradas seis classes de produtividade nas plantações de Eucalyptus grandis, a mais produtiva com IMA variando de 69 a 77 $\mathrm{Stc} / \mathrm{c} \mathrm{ha}{ }^{-1} \mathrm{ano}^{-1} \mathrm{e}$, a menos produtiva, com IMA variando de 32 a $39 \mathrm{Stc} / \mathrm{c} \mathrm{ha}^{-1} \mathrm{ano}^{-1} \mathrm{com}$ relações diretas entre as características físicas e químicas dos solos. Quando foram associadas algumas variáveis edáficas em análises de regressão múltipla, o IMA pôde ser previsto com alta precisão $\left(R^{2} \geq 0,97\right.$ e $\left.p<0,01\right)$. Nestas análises, as variáveis que mais explicaram as diferenças de produtividade foram os teores de areia, $\mathrm{MO}$ e $\mathrm{opH}$. Os métodos de geoprocessamento usados simplificaram, agilizaram e aumentaram a precisão dos procedimentos de espacialização e visualização das informações processadas. 


\title{
SOILS AND PRODUCTIVITY MAPPING IN Eucalyptus grandis PLANTATIONS USING GEOPROCESSING AT THE EXPERIMENTAL STATION OF ITATINGA, ESALQ
}

\author{
Author: THAIS DIAS GONÇALVES \\ Adviser: Prof. Dr. JOSÉ LEONARDO DE MORAES GONÇALVES
}

\section{SUMMARY}

This work had as objective to do the fisiographic characterization, to complement the soil classification and survey, to do the productivity mapping of the eucalypt stands and to identify the relations between forest productivity and edaphic attributes at the Experimental Station of Itatinga, ESALQ/USP, using field survey techniques, laboratorial analysis and geoprocessing. For structuring the digital cartographic base, as primary source of data, satellite images, aerial photographs and field prospecting were used and, as secondary source, topographical, pedologic, geological and land occupation maps were used. The analogical plan-altimetric map was obtained starting from topographical maps in scale 1:10,000, elaborated by the Geographical and Cartographic Institute of São Paulo State (IGC). From the images scannered (raster), the software AutoCAD R14 for heads-up digitalization (vectorization) was used. From the altimetric map, generated in the software AutoCAD R14, the file digitalized was converted of the format DXF for DAT, with the software DXF3DAT and than the regular grid was exported to the Idrisi for Windows 2.0 software. Hypsometric and sloping maps were generated in the Idrisi, what made possible to separate in classes the altitude and the slope, using the "reclass" routine. With the pedologic map of part of E.S. of Itatinga, the altimetric map and field prospecting and soil characterization and survey of the area no mapped, the detailed pedologic map of 
all the station was elaborate. For the productivity mapping, inventory data of permanent plots (same species, provenance and age) obtained in Eucalyptus grandis plantations (grew up between 1991 to 1997) was used. For the definition of the productivity classes, the Mean Annual Increment (MAI) of the solid volume of wood with bark was chosen as productivity indicator, because it presented the higher correlation with the edaphic characteristics. By means of simple correlation analysis and of multiple regression analysis (stepwise procedure, backward model), the variable dependent, MAl of the E. grandis stands were related with some physical and chemical soil characteristics. Two standards of level curves standards were identified, one with close, narrow and surrounding curves to the drainage channels, in the steeper areas with smaller altitude; another, with spaced curves, present in the higher altitude areas, where the relief is plan or soft wavy. Narrowly related with the fisiographic standards, five soil classes were characterized. Six productivity classes in Eucalyptus grandis plots were found, the most productive with MAI ranging from 69 to $77 \mathrm{Stc} / \mathrm{c} \mathrm{ha}^{-1}$ year-1 and, the least productive, with MAI ranging from 32 to 39 $\mathrm{Stc} / \mathrm{c} \mathrm{ha}^{-1}$ year ${ }^{-1}$. These productivity ranging presented direct relationships with the physical and chemical soil characteristics. When some edaphic variables were associated by multiple regression, the MAI could be estimated with high precision $\left(R^{2} \geq 0.97\right.$ and $p<$ $0.01)$. In these analysis, the variables that explained most the productivity differences were the sandand organic matter contents and $\mathrm{pH}$. The geoprocessing methods simplified, hastened and increased the precision of spacialization and visualization procedures of the processed information. 


\section{INTRODUÇÃO}

A caracterização ambiental detalhada de uma propriedade rural é imprescindível para seu planejamento técnico e financeiro, tanto do ponto de vista científico, como de aplicação tecnológica, ao servir como elemento de transferência de informações e experiências, portanto, como mecanismo de previsão. Dessa forma, o planejamento da pesquisa ou da produção florestal conta com subsídios fundamentais para a definição de práticas de manejo florestal mais precisas e adequadas, proporcionando menor potencial de impacto ambiental, melhor entendimento de relações entre causa e efeito nos projetos de pesquisa e possibilidade de aumento da produtividade e rentabilidade florestal dentro de uma perspectiva mais sustentável de manejo. Da perspectiva legal, segundo a legislação brasileira, o uso de uma propriedade rural deve ser pautado com base num plano de manejo técnico, fundamentado nas características climáticas, fisiográficas, hídricas, edáficas e florísticas das bacias hidrográficas.

Para se fazer à caracterização fisiográfica, o levantamento pedológico e o mapeamento da produtividade florestal, o geoprocessamento é uma ferramenta muito útil e prática, pois facilita a espacialização e visualização das informações, tornando os resultados mais abrangentes, precisos, padronizados e melhor apresentados, possibilitando múltiplas combinações e interações de informações no sentido de aprimorar o manejo florestal (Hertz et al., 1991; Roy et al., 1996; Ito, 1998).

Este trabalho teve como objetivos fazer a caracterização fisiográfica, complementar o levantamento pedológico, fazer o mapeamento da produtividade de plantações de eucalipto e identificar relações entre produtividade florestal e características edáficas na Estação Experimental de Itatinga (ESALQ/USP), com uso de técnicas de levantamento de campo, análises laboratoriais e geoprocessamento. 


\section{REVISÃO DE LITERATURA}

\subsection{Estimação da produtividade florestal}

Para a classificação de sítios florestais quanto aos seus potenciais produtivos, passa-se por várias etapas (modificado de Carmo et al. 1990):

- identificação e delimitação de sítios florestais;

- estimativa de redução das limitações ao desenvolvimento e crescimento das árvores;

- viabilidade de redução dessas limitações por meio de práticas silviculturais;

- avaliação da interação sítio-espécie, por meio de modelos de predição da produção florestal; e

- ordenamento dos sítios quanto às classes de manejo ou potencial de resposta à prática silvicultural.

Dois métodos são comumente usados para estimar a produtividade de sítios florestais: o direto, em que a produtividade do sítio é estimada diretamente das avaliações de crescimento das árvores que ocorrem no sítio e, o indireto, em que a produtividade do sítio é estimada indiretamente por meio de variáveis ambientais (climáticas, fisiográficas e edáficas) ou de plantas indicadoras (por ex., invasoras do sub-bosque). Neste caso, dispensando a presença de povoamentos florestais adequados para as avaliações de crescimento (Gonçalves, 1990). Entre os métodos indiretos, os mais empregados no setor florestal têm sido o levantamento de solo e os modelos de análise multivariada de relação solo-sítio (Barros, 1974; Gonçalves, 1990). As técnicas de geoprocessamento têm sido usadas em ambos os métodos (Campo, 1982; Biggs \& Spencer, 1990; Couto \& Vettorazzi, 1991; Roy et al., 1996; Ito, 1998). Os métodos citados são a base para realização de um plano de manejo para áreas de florestamento. Lima (1998) avalia que o 
plano de manejo florestal possibilita o acompanhamento da evolução das características ambientais, o que evita a destruição de ecossistemas, da biodiversidade, a degradação de microbacias, a diminuição da reserva de nutrientes do solo e a desfiguração da paisagem.

\section{Método direto}

Neste método, são utilizadas medidas de Inventário Florestal que são correlacionadas com valores padrões; há, ainda, a utilização de valores referentes à produção de celulose, resina, carvão e equivalentes calorificos de madeira e outros, dependendo dos objetivos finais da atividade florestal (Gonçalves, 1990).

Com periodicidade anual, o inventário florestal permanente monitora o desenvolvimento da floresta quanto ao crescimento, mortalidade e regeneração, e possibilita a estimativa de danos ecológicos da exploração (Amaral et al., 1998). Existem diversos métodos para estimativa do incremento e crescimento das árvores: métodos simples, medições sucessivas em árvores aleatórias, bandas perimetrais e medições dos anéis de crescimento (Klepac, 1976). Para avaliação da biomassa arbórea do plantio, é aconselhável a obtenção das seguintes medidas: DAP, altura do tronco, profundidade e largura da copa de um conjunto representativo das árvores da parcela permanente (Alder, 1980).

No caso de medidas de inventário, utiliza-se Índice de Sítio (IS), Volume Sólido de madeira com casca (VM), Incremento Médio Anual (IMA) e Altura Média das Árvores (HM). Atualmente, as medidas mais utilizadas são IS e IMA, já que pesquisas comprovaram que essas apresentam melhor relação com a qualidade do sítio (Couto, 1990).

Alder (1980) cita que a altura de uma árvore uniforme em uma determinada idade é bom indicador do potencial produtivo de bosques homogêneos e, em particular, do sítio. O IMA é utilizado para caracterização abrangente da produtividade florestal, porque possibilita fazer correlações com características ambientais representativas do local (clima, fisiografia 
e solos), podendo resultar em regressões múltiplas que permitem distinguir áreas homogêneas quanto ao potencial produtivo (Klepac, 1976; Alder, 1980; Couto, 1990). O IMA é obtido em parcelas simples, pela diferença entre as medições sucessivas do diâmetro dividida entre o intervalo de tempo transcorrido (Alder, 1980).

\section{Método indireto}

Nesse método, parcelas de povoamentos florestais são relacionadas a diferentes capacidades produtivas, em função das diferenciações climáticas, fisiográficas e edáficas. Segundo Carmo et al. (1990), é realizada uma correlação direta entre características da espécie utilizada, por exemplo, IS, IMA e VM, com as características climáticas, fisiográficas e edáficas avaliadas em análises estatísticas. As características climáticas que influenciam diretamente no desenvolvimento do plantio florestal são temperatura e precipitação, mas são os extremos de ambos que podem comprometer a produtividade (Monteiro, 1971). Braga et al. (1999) mencionam as vantagens da utilização de características fisiográficas em levantamento de produtividade de plantio, por serem de fácil levantamento, seja no campo ou por meio de técnicas de Sensoriamento Remoto, além de não se alterarem ao longo do tempo, facilitando a classificação dos sítios.

A avaliação de características edáficas visando estimar a produtividade florestal pode ser difícil, devido à imprecisões de amostragem, metodológicas e a múltiplas interações de variáveis. Segundo Gonçalves (1990), nem sempre as unidades pedológicas descritas em mapas pedológicos coincidem com as unidades de qualidade do sítio, devido à concepção eminentemente agrícola do sistema de classificação do solo, que definem classes e padrões de características fisiográficas e pedológicas nem sempre diretamente relacionadas ao crescimento das árvores.

Costa et al. (1990) e Pritchett (1990) destacam que nos estudos de relação solo-sítio, as propriedades físicas do solo apresentam maior relação com a produtividade do que as propriedades químicas, por serem relacionadas com propriedades edáficas fundamentais para as plantas, como a capacidade de retenção de água disponível e a permeabilidade do solo. Gonçalves (1990) avaliou que, dentre as características químicas 
do solo, as que apresentaram maior correlação com o crescimento de plantações de eucaliptos, em ordem decrescente, foram o pH, os teores de matéria orgânica, de $\mathrm{P}$ disponível, de $\mathrm{N}$ total, de $\mathrm{K}$, de Ca e Mg trocáveis. No Brasil, o plantio florestal, em geral, é realizado em solos de baixa fertilidade com potencial produtivo limitado pelo horizonte superficial e, em alguns casos, apenas aos primeiros centímetros dessa camada. Esses solos, comumente Latossolos, Argissolos e Neossolos Quartzarênicos, são antigos e desgastados pelo tempo (Carmo et al., 1990).

\subsection{Geoprocessamento}

Geoprocessamento é o conjunto de tecnologias de coleta e de tratamento da informação espacial, assim como o desenvolvimento de novos sistemas e aplicações, utilizando técnicas matemáticas e computacionais para o tratamento da informação geográfica (Rodrigues, 1987). A tecnologia utilizada neste sistema envolve hardware e software, ou seja, equipamentos e programas (Ferreira, 1995). O uso do geoprocessamento no Brasil tem se difundido largamente e, aumentada sua margem de aplicação, passou a atuar também em planejamentos, gerenciamento e caracterização de diferentes locais no país (Argento \& Marques, 1988; Hertz et al., 1991; Campos, 1996; Zákia, 1998).

As técnicas de geoprocessamento são divididas em três áreas: Cartografia Digital, Sensoriamento Remoto e Sistemas de Informação Geográfica (SIG). O desenvolvimento da Cartografia Digital iniciou na década de 70, com o surgimento do software CAD (Computer Aided Design), que trouxe novo dinamismo às cartografias temática e sistemática. O Sensoriamento Remoto é definido como a coleta e processamento de informações sobre o ambiente terrestre, particularmente seus recursos naturais e culturais, pelo uso de dados de imagens adquiridos em aeronaves ou satélites (Fisher \& Lindenberg, 1989). Um dos produtos mais conhecidos e utilizados são derivados de sistemas sensores multiespectrais: os scanners como os do sistema LANDSAT, esses satélites disponibilizam um conjunto de imagens com registro de radiância ao longo de intervalos de bandas espectrais. No caso do sistema LANDSAT, o scanner multiespectral (MSS), tem 80m e 4 bandas; já o mapeador temático (TM), 30 m e 7 bandas (Novo, 1992). 
A interpretação de imagens pode ser realizada devido à resposta espectral obtida conforme a natureza do objeto e a região do espectro a ser utilizada (azul, verde, vermelho, I.V. próximo, I.V. médio e I.V. termal), em casos específicos, pode-se fazer uma composição de bandas em que a interpretação do elemento apresenta-se mais satisfatória. A interpretação de imagens de Sensoriamento Remoto pode ser feita visualmente e pelo uso de softwares específicos para este fim. A interpretação visual conta com diversos elementos que o fotointérprete pode utilizar, como: cor, textura, tamanho, forma, padrão, altura, localização e contexto. Na interpretação auxiliada por computador, é usada, com maior freqüência, o padrão de resposta espectral (Eastman, 1997).

A terceira área do Geoprocessamento é o SIG. Fisher \& Lindenberg (1989) trazem uma conceituação que divide o SIG em tecnologia e problema-alvo. Como técnica, Burrough \& Frank (1995) define SIG como um poderoso conjunto de instrumentos que possibilita coletar, armazenar, manipular, transformar e exibir dados espaciais, que são a representação do mundo real, de acordo com os propósitos de trabalho. Concentrandose no problema-alvo, Goodchild (1985) define SIG como um sistema que usa um banco de dados espacial para produzir respostas às questões de natureza geográfica e que enfatizam a natureza analítica dos sistemas.

Essa ciência da Informação Espacial funciona como uma entrada de dados, formando mapas temáticos também chamados de layers ou Planos de Informação (PIs). Esses layers são manipulados pelo formato varredura, por meio de operações matemáticas e lógica booleana. O SIG trabalha com dois tipos básicos de representação espacial: vetorial e raster. Como modelos da realidade, ambos representam fenômenos de espaço e têm méritos e utilidade, dependendo do que se precisa realizar. Vetores trabalham com condições espaciais de precisão como linhas, pontos e polígonos (Mafini, 1987). A estrutura raster é representada por células, também chamada malha ou grid, que podem ser quadradas, triangulares ou retangulares (Mafini, 1987). 


\section{MATERIAL E MÉTODOS}

\subsection{Caracterização da área experimental}

A Estação Experimental de Itatinga, com 2.153 ha, está localizada entre os paralelos $23^{\circ} 02^{\prime}$ a $23^{\circ} 07^{\prime}$ latitude sul, e os meridianos $48^{\circ} 35^{\prime}$ a $48^{\circ} 39^{\prime}$ longitude oeste, no município de Itatinga, SP (Figura 1). Sua efetivação como Estação Experimental ocorreu com a incorporação ao patrimônio da Universidade de São Paulo em 28 de julho de 1988 (Lima, 1989). O clima da região é, segundo classificação de Köppen, Cwa: úmido e quente no verão, seco e frio no inverno. A precipitação média anual é de $1500 \mathrm{~mm}$, com 48\% concentrada no verão, $23 \%$ na primavera, $21 \%$ no outono e $8 \%$ no inverno. Pelo balanço hídrico de Thornthwaite \& Mather (1955), não há déficit hídrico. A temperatura média é de $20^{\circ} \mathrm{C}$, com mínima de $7,4^{\circ} \mathrm{C}$ em julho e máxima de $28,8^{\circ} \mathrm{C}$ em janeiro (Figura 2).

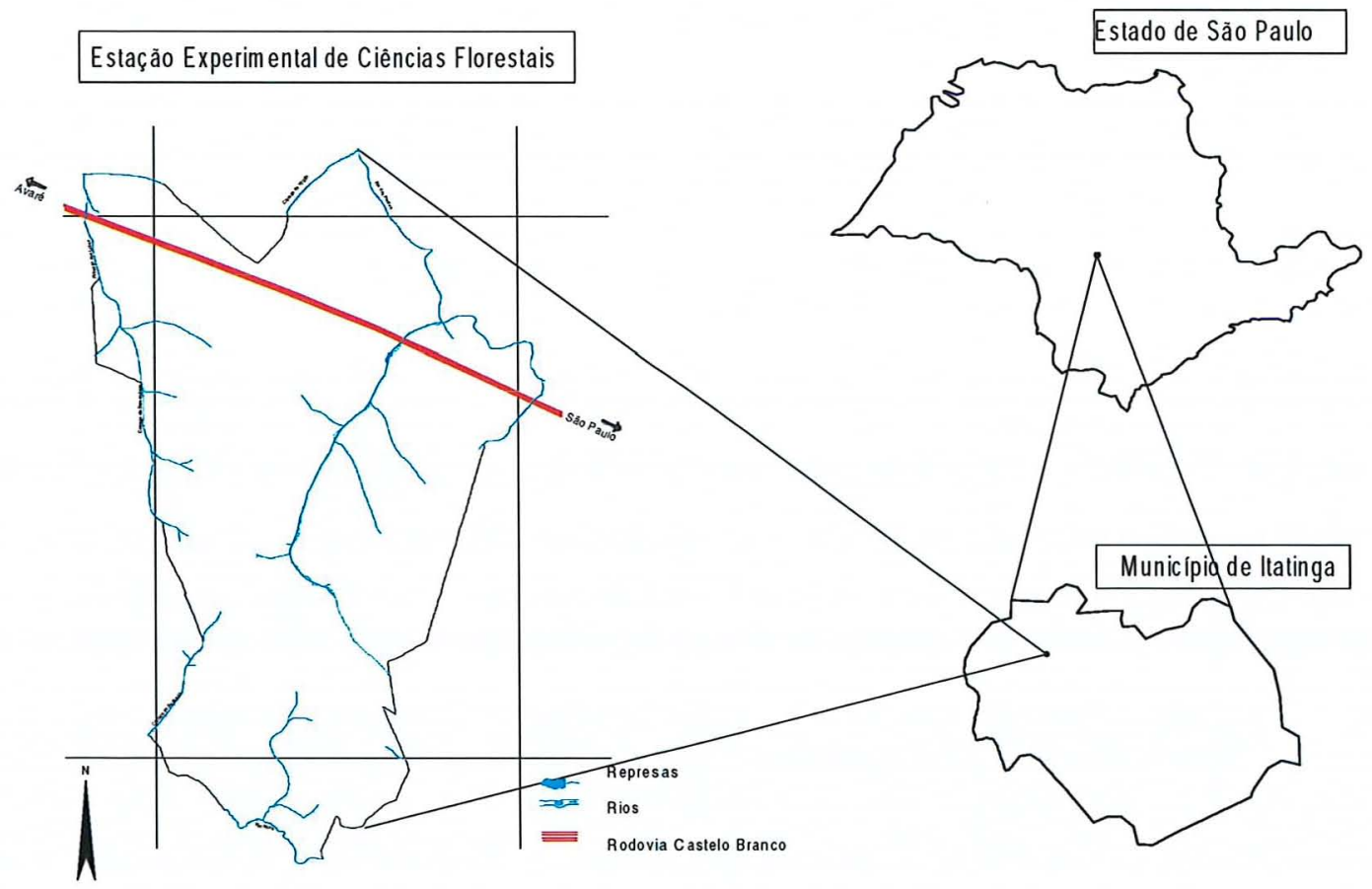

Figura 1 - Mapa de Localização da Estação Experimental de Itatinga. 
A geologia da área é do período Cretáceo, em duas litologias distintas: arenítica, formação Marília, do Grupo Bauru, e basáltica, formação Serra Geral, do Grupo São Bento. O Grupo Bauru caracteriza-se pela presença de arenitos com granulação fina a grossa, compreendendo bancos maciços em tênues estratificações cruzadas de médio porte. Subordinadamente ocorrem lentes de siltitos, argilitos e arenitos muito finos. Há presença de nódulos carbonáticos. O grupo São Bento destaca-se pela presença de rochas vulcânicas dispostas em derrames basálticos com coloração cinza a negra, textura afanítica, com intercalações de arenitos intertrapeanos, finos a médios, apresentando estratificação cruzada tangencial vitrofíricos não individualizados (IPT, 1984).

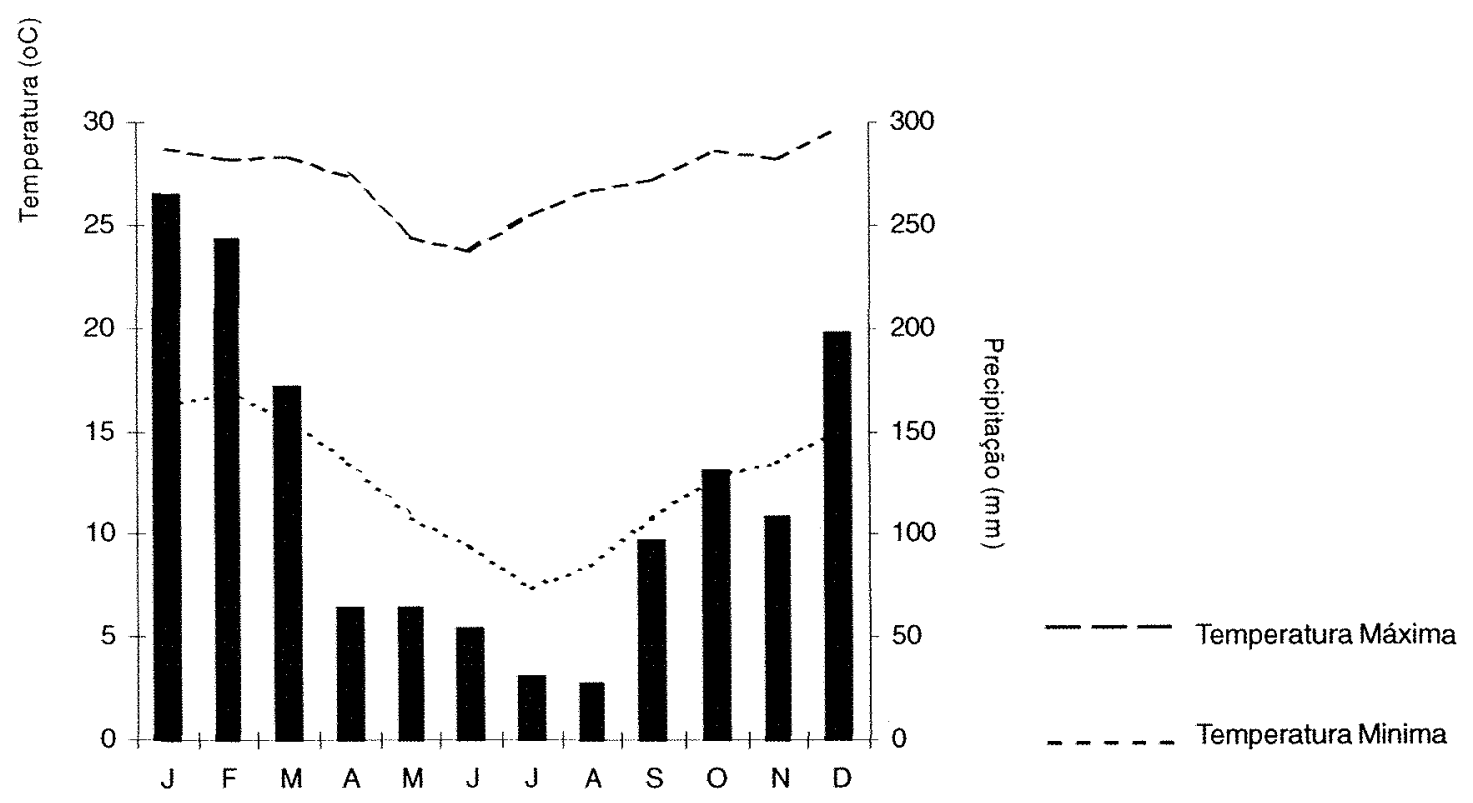

E E. de Itatinga, Itatinga-SP, Brasil

$\left(23^{\circ} 00^{\prime} \mathrm{S}, 48^{\circ} 42^{\prime} \mathrm{O}\right) 850 \mathrm{~m}$

Figura 2 - Média da variação anual de precipitação e de temperatura máximas e mínimas na E.E. de Itatinga (1991 - 2001).

A região que compreende a E.E. de Itatinga apresenta relevo típico do Planalto Ocidental Paulista, com relevo variando entre suave ondulado a plano, topos aplainados e encostas retilíneas ou convexas. A altitude máxima é $863 \mathrm{~m}$, a nordeste da área. $\mathrm{Na}$ rede de drenagem predomina um padrão de baixa densidade, subdendrítico, com cabeceiras de drenagem em forma arredondada e vales abertos a fechados, com planície aluvial restrita (Pessotti, 1995). 
De acordo com levantamento pedológico detalhado de parte da área (Pessotti, 1995), são encontrados os seguintes solos: Latossolo Vermelho-Amarelo Distrófico típico A moderado textura média; Latossolo Vermelho Distrófico típico A moderado texturas argilosa e média e Latossolo Vermelho Distroférrico típico A moderado textura argilosa, pelo Sistema Brasileiro de Classificação de Solos (EMBRAPA, 1999).

A área da E.E. de Itatinga está ocupada com vegetação nativa, plantações florestais e infra-estrutura. A vegetação nativa compreende vegetação de brejo, florestas ciliares e Floresta Estacional Semidecidual Submontana (Veloso, 1992). As plantações florestais são monoespecíficas e equiâneas, em sua maioria, eucaliptos e pinus. As áreas destinadas à preservação permanente e reserva legal ocupam 485 ha, $28 \%$ da área total (Figura 3).

a

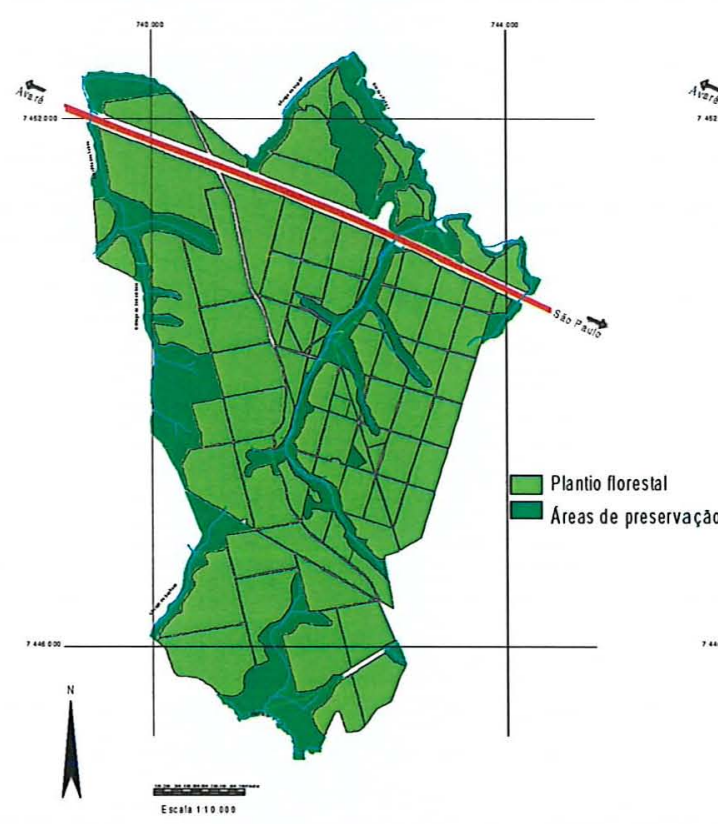

b

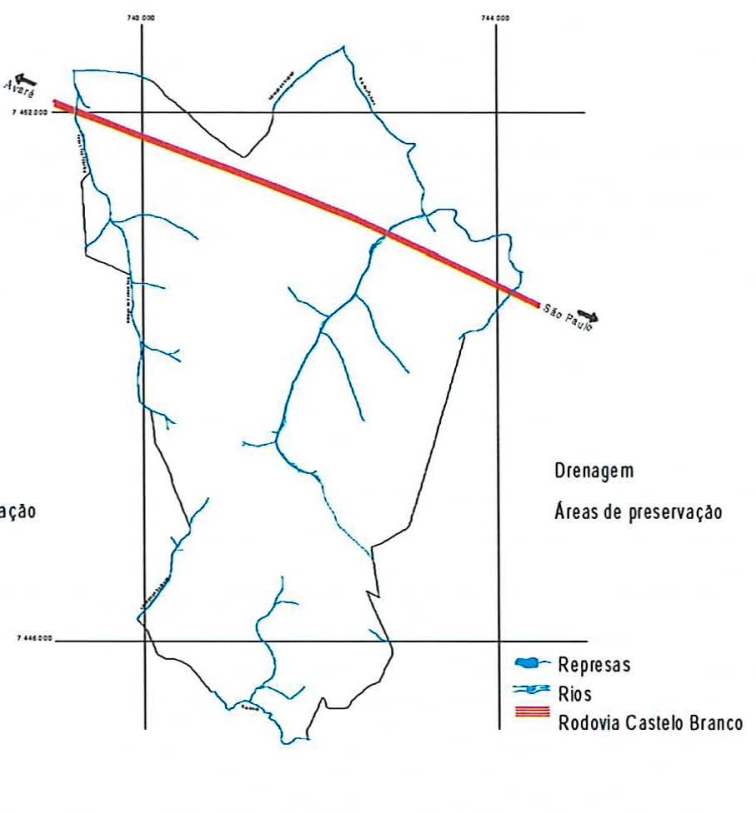

Figura 3 - (a) Área atualmente preservada e (b) área que deve ser legalmente preservada.

Baseado no Código Florestal Brasileiro (Brasil, 1980), pelo critério da declividade, toda área da E.E. de Itatinga pode ser usada para projetos silviculturais sem restrição, bastando para isso um plano específico de manejo florestal. A área em uso para produção florestal é de 1636 ha, sendo 603 ha reservados à experimentação, o restante, arrendado para produção florestal (Tabela 1). Atualmente, estes talhões estão sendo ocupados com plantações de eucaliptos (autofuste), cerca de quatro anos, plantados após o corte raso de povoamentos de eucalipto com sete anos. 
Tabela 1. Uso do solo na E.E. de Itatinga

\begin{tabular}{lcc}
\hline \multirow{2}{*}{ Uso do solo } & \multicolumn{2}{c}{ Área } \\
& Absoluta & Relativa \\
\hline & ha & $\%$ \\
Florestamento comercial & 1033 & 48 \\
Área experimental & 603 & 28 \\
Preservação permanente & 517 & 24 \\
\hline
\end{tabular}

\subsection{Morfometria do relevo}

As paletas de cores utilizadas para representar os intervalos de classes utilizados em todos os mapas foram criadas com base no método de representação gráfica da Semiologia (Bertin, 1986), em que uma variável ordenada deve ser representada por variáveis visuais que expressam "valor" e "granulação". Neste trabalho utilizou-se cor, que é uma variável seletiva e ordenada. As informações classificadas apresentam características ordenadas em intervalos de classe quantitativos ou qualitativos (Castro et al., 1998).

Para a estruturação da base cartográfica digital, como fontes primárias de dados foram usadas imagem de satélite, fotografias aéreas e levantamentos de campo e, como fontes secundárias, cartas topográficas, mapa pedológico, mapa geológico e mapa de uso e ocupação do solo. O mapa planialtimétrico analógico foi obtido a partir de cartas topográficas em escala 1:10.000, elaboradas pelo Instituto Geográfico e Cartográfico do Estado de São Paulo - IGC: Córrego do Lobo, Ribeirão das Pedras, Córrego Potreirinho, Fazenda Toca e Fazenda Rio Novo, que compõem a articulação apresentada na Figura 4. A partir das imagens scanerizadas (raster) utilizou-se o software AutoCAD R14 para a digitalização "heads-up" (vetorização), isto é, digitalização pela tela do computador, da área limite, das curvas de nível, dos pontos cotados e da rede de drenagem, posteriormente, edição vetorial das cartas. Foram atribuídos os valores correspondentes $(Z)$ aos pontos cotados e às curvas de nível, sendo estas eqüidistantes em $5 \mathrm{~m}$. A geração da imagem corresponde ao retângulo envolvente da região de estudo, em coordenadas 
plano-retangulares: $X \min =739.000 \mathrm{~m} ; X \max =745.000 \mathrm{~m} ; Y \min =7.444 .000 \mathrm{~m}$; $Y \max =7.452 .000 \mathrm{~m}$, com resolução de 30 metros, na escala 1:10.000 e em projeção UTM.

Para a geração do modelo digital do terreno (MDT) por meio de manipulação do software de modelagem SURFER, o arquivo digitalizado foi convertido do formato DXF para DAT, com uso do software DXF3DAT. Para geração do MDT, os pontos de coordenadas e a altimetria foram representados em mapa por interpolação usando o método da

SF-22-Z-B $-11-2$

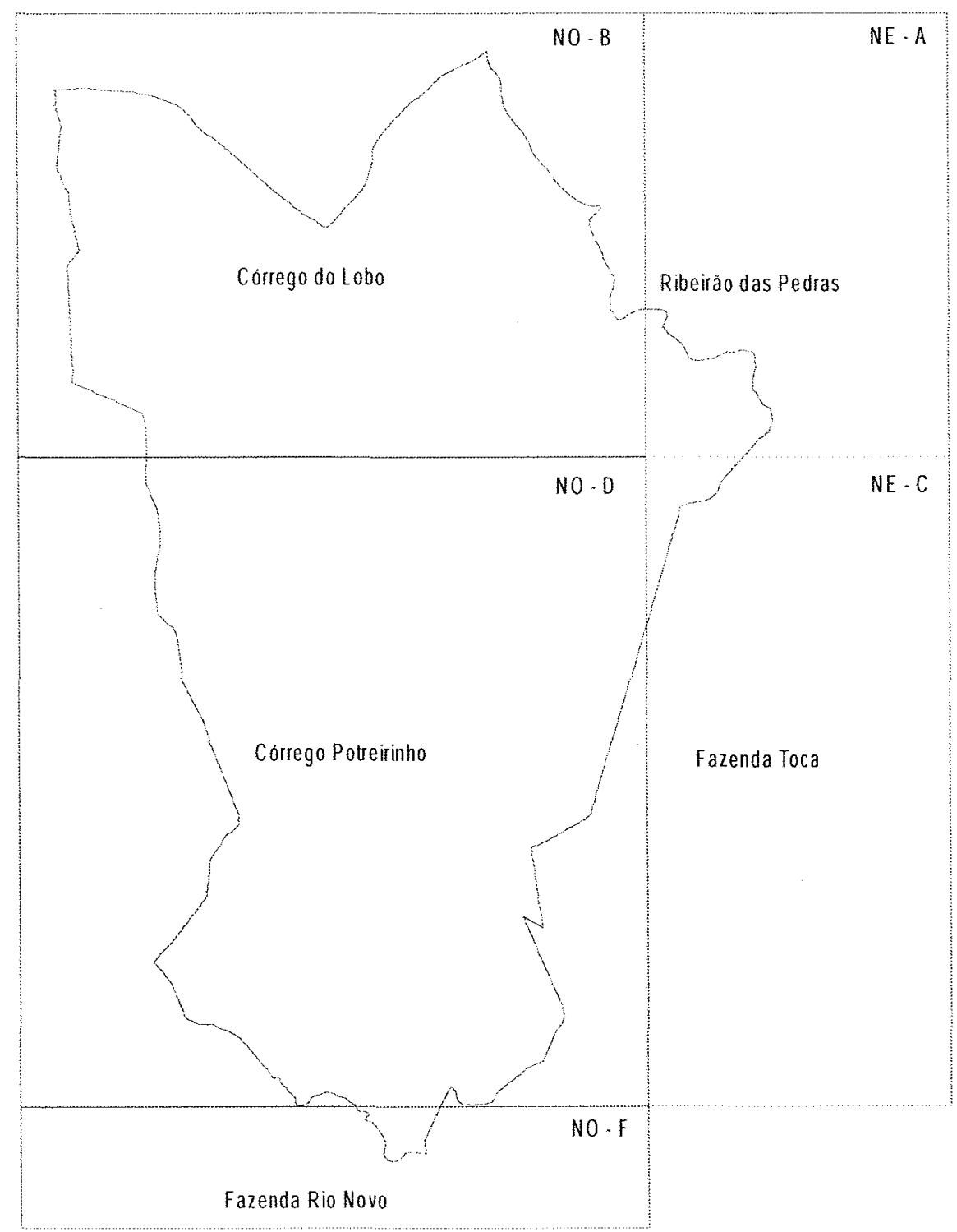

Figura 4 - Mapa de articulação das cartas topográficas na E.E. de Itatinga. 
Krigagem, gerando uma grade regular correspondente à área de estudo, necessária para representar a tridimensionalidade dos dados. O processo de interpolação consistiu em estimar os valores de variáveis locais onde existiam dados, dentro de uma área com valores medidos, no caso, as curvas de nível e os pontos cotados. Os parâmetros de distribuição espacial usados nessa interpolação foram histograma, variograma e anisotropia.

A partir do mapa planialtimétrico gerado em software $C A D$ foi criado o mapa de declividade. Foi necessário exportar o arquivo DXF (AutoCAD) para o arquivo vetorial do software de geoprocessamento, IDRISI for Windows $2.0 \mathrm{e}$, a partir daí fazer a conversão para arquivo raster, ou seja, em formato matricial. A rotina utilizada chama-se "surface" (um operador de contexto), que atribui novo valor de pixel, baseando-se no valor de pixels ao redor, usado para calcular declividades (Eastman, 2000). Posteriormente, fez-se a reclassificação, com a rotina "reclass", do mapa de declividade obtido, o que possibilitou detectar áreas que, seguindo a legislação do Código Florestal Brasileiro (Brasil, 1980), são aptas ou inaptas ao plantio, de acordo com a declividade do terreno. Para geração desse mapa, optou-se pelo agrupamento em quatro classes (750 a $775 \mathrm{~m}, 775$ a $800 \mathrm{~m}$, 800 a 825 me 825 a $863 \mathrm{~m}$ ), que melhor representaram a variação de altitude. A simbologia utilizada na representação das classes foi a de cores, com uma variação gradativa, com tons mais escuros em classes de maior declividade.

No mapa que delimitou as áreas de preservação permanente, foi utilizada a rotina "buffer", que atribui pixels de influência da rede drenagem para distinguir as faixas de mata ciliar de acordo com a largura dos canais de drenagem. O critério utilizado foi o do Código Florestal Brasileiro (Brasil, 1980): largura mínima de $30 \mathrm{~m}$ para cursos d'água com menos de $10 \mathrm{~m}$ de largura e $50 \mathrm{~m}$ de diâmetro para nascentes.

Para melhor definição dos padrões de utilização da área, esta foi subdividida em duas áreas: a primeira, restrita à experimentação da Universidade de São Paulo, com gestão do Departamento de Ciências Florestais da ESALQ/USP, denominada no mapa como talhão "A", e, a segunda área, arrendada à empresa florestal Cia Suzano de Papel e Celulose S.A., usada para plantações de eucalipto, denominada no mapa como talhão "B" (Figura 5). Nesse mapa, obteve-se o primeiro plano de informação a partir de uma composição de outros mapas, ou seja, a partir de atributos múltiplos usando operações 
matemáticas $\left(+-/^{\star}\right)$ entre duas imagens booleanas (Eastman, 2000). Aqui se somou o mapa em que o critério de declividade indicava a inadequação da área para o plantio $\left(>45^{\circ}\right)$, bem como possibilitava delimitar as áreas de preservação permanente.

Na etapa de realização do mapa de uso e ocupação do solo, foram utilizados diferentes materiais para interpretação visual, que se complementaram: i) fotografias aéreas (adquiridas em 24/01/1999), resolução de 0,5 m para um pixel, em escala 1:10.000, de excelente visualização, mas com apenas $40 \%$ da área; ii) imagem de satélite LANDSAT/ TM (adquirida em 2/9/99), bandas 3, 4 e 5, órbita 220, ponto 76, resolução espacial de 30 m, fornecida pelo Instituto Nacional de Pesquisas Espaciais (INPE) no formato TIFF e nível de correção 4; iii) mapa de uso e ocupação existente (Stape, 1998); e iv) observações de campo. O processamento digital do mapa existente e suas atualizações foram realizados por meio de digitalização em softwares CAD e de geoprocessamento, assim como o cálculo de áreas. Houve desvio do layer planialtimétrico em relação ao layer de uso e ocupação do solo, decorrente de problemas operacionais com a escala do mapa de uso e ocupação do solo analógico utilizado (Stappe, 1981) na criação da base de dados, que permitiu uma pequena margem de erro no cálculo de áreas; o que não invalida a proposta metodológica.

\subsection{Mapa detalhado de solos}

As etapas do mapeamento pedológico incluíram prospecções de campo, caracterizações morfológicas, físicas, químicas e, e classificação taxonômica e distribuição das unidades pedológicas no mapa segundo o Sistema Brasileiro de Classificação dos Solos (EMBRAPA, 1999). O método utilizado para o levantamento dos solos foi o de observações ao longo de transectos que cruzam toda paisagem, ou seja, observações em linhas de caminhamento que atravessam todas unidades fisiográficas. Procurou-se, em cada uma delas, efetuar várias tradagens e amostragens que cobrissem todas as toposseqüências das vertentes, desde as partes baixas até o topo das elevações, com caminhamento em ziguezague acompanhando a declividade do terreno. A amostragem de solo foi realizada em 40 pontos, onde se 


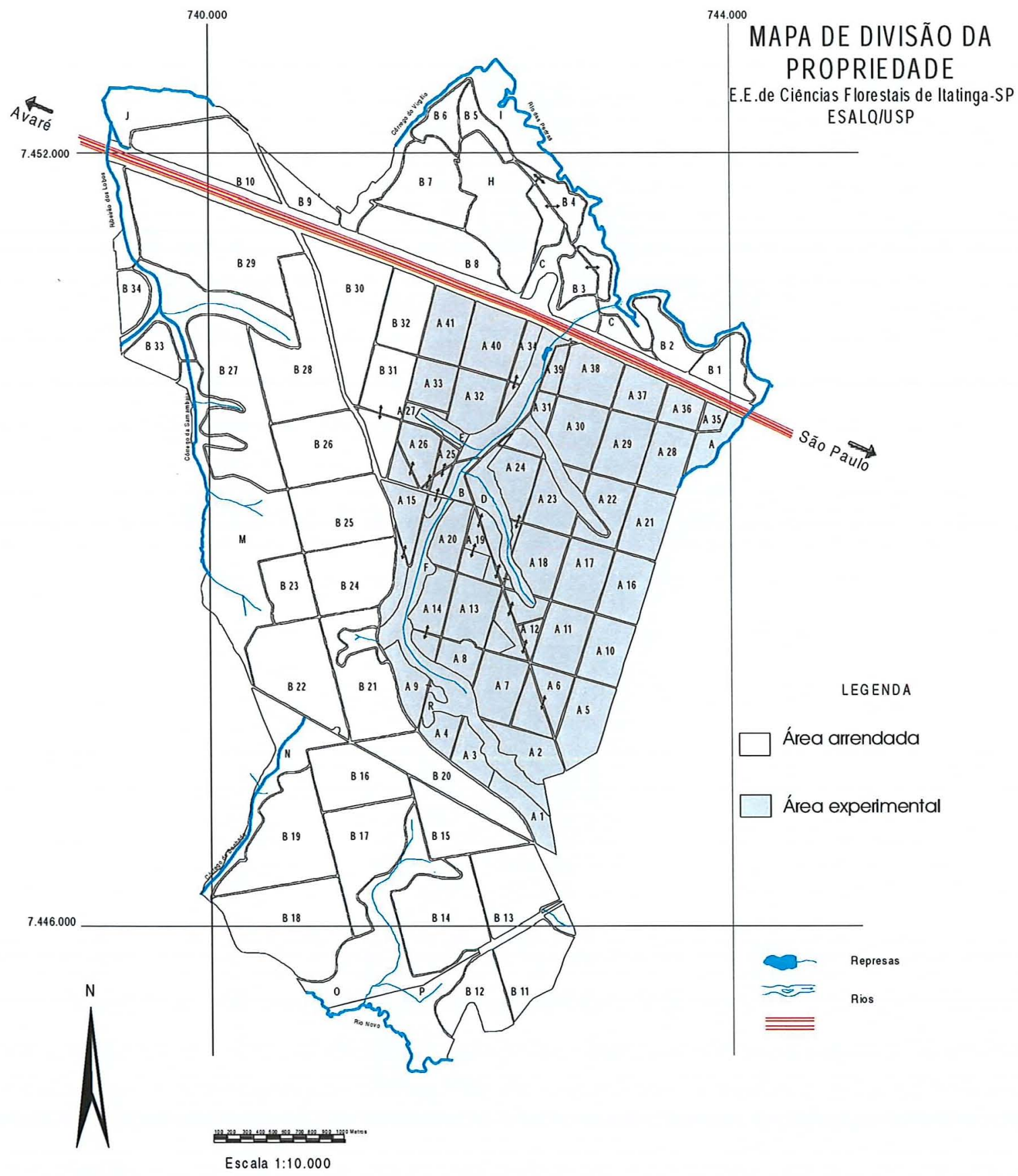

Figura 5 - Mapa de divisão da E.E. de Itatinga. 
coletaram amostras de dois horizontes do solo ( $\mathrm{A}$ e $\mathrm{B}$ ). Os pontos amostrados também tiveram como critério de escolha as classes de altitude encontradas no mapa hipsométrico. Obteve-se uma densidade amostral de 24,9 ha por ponto de amostragem, mais 12 trincheiras para descrição morfológica.

Na descrição morfológica do solo, baseadas no Manual de Descrição e Coleta de Solos no Campo (Lemos \& Santos, 1996), observaram-se aspectos gerais da paisagem, particularmente o crescimento do plantio florestal e as características do solo, visíveis em trincheiras, barrancos e estradas, o que possibilitou relacionar as informações encontradas com as contidas nos mapas hipsométrico, planialtimétrico e de declividade. Todas as informações coletadas no campo foram locadas no mapa planialtimétrico. Nessa fase, demarcaram-se os locais onde foram coletadas as amostras para posterior caracterização de unidades representativas do solo, utilizandose para isso a relação silte/argila e a cor da amostra, de acordo com a escala Munsell Soil Color Charts (1975). A aferição do mapa foi realizada por meio de amostragem espacial, objetivando uma redução dos custos de levantamento detalhados.

As amostras de solo foram secas em estufa a $40-45^{\circ} \mathrm{C}$ até peso constante, e depois peneiradas, obtendo-se a terra fina seca em estufa (TFSE). Posteriormente, a TFSE foi submetida a análises físicas e químicas. As análises físicas realizadas foram a de granulometria e a de densidade de solo e de partícula (EMBRAPA, 1999). A granulometria foi determinada por sedimentação em cilindro Koettgen, sendo usado calgon (hexametafosfato de sódio $1,0 \%$ ) e hidróxido de sódio $(0,4 \%)$ como agentes de dispersão. A agitação das amostras foi em alta rotação, durante 15 minutos. As frações areia grossa, areia média, areia fina foram separadas por tamisação em peneiras de malha 0,2 e 0,05 mm de diâmetro, respectivamente. Para a determinação da fração argila foi utilizada o hidrômetro de Boyoucos (Vettori \& Pierantoni, 1968). A fração silte foi determinada pela diferença entre a massa da TFSE e a massa de areia total mais argila. Para as análises químicas de $\mathrm{pH}$ em $\mathrm{H}_{2} \mathrm{O}, \mathrm{KCl} e \mathrm{CaCl}_{2}$, de carbono orgânico e de fósforo, bases e alumínio trocáveis por resina aniônica e acidez titulável, usaram-se os métodos indicados por Raij et al. (2001). 


\subsection{Mapa de produtividade}

$\mathrm{Na}$ área arrendada, os dados de inventário das parcelas permanentes (mesma espécie, procedência e idade) obtidos nas plantações florestais conduzidas entre 1991 a 1997 foram usados para mapeamento da produtividade e em análises multivariadas preditivas da produtividade florestal, em que se relacionou a produtividade com características das unidades pedológicas descritas. A área arrendada e plantada com Eucalyptus grandis (procedência Mogi Guaçu), 1033 ha, é composta por 34 talhões, onde é realizado o inventário florestal continuamente.

Para a definição das classes de produtividade, escolheu-se como indicador de produtividade o Incremento Médio Anual (IMA) do volume sólido de madeira com casca, pois foi o que apresentou maiores correlações com as características edáficas (análises expeditas). Os dados do $6^{2}$ ano de plantio foram usados como base e a definição dos intervalos de classe de produtividade foram obtidos pela fórmula de Sturges, que dá estimativa do número de classes a ser usada (Gerardi \& Silva, 1981):

$$
K=1+3,3 \log n
$$

Em que, $k$ é o número total de classes, log é o logaritmo na base 10 e $n \circ$ número total de observações.

Por meio de análises de correlação simples e de regressão múltipla, tipo stepwise, modelo backward, a variável dependente, IMA (6 anos de idade) dos povoamentos de $E$. grandis foram relacionadas com as variáveis independentes, algumas características físicas e químicas dos solos (argila, silte, areia, M.O., pH, K, Ca, Mg, Al e CTCe). As análises foram realizadas pelo software Statgraphs Plus. 


\section{RESULTADOS E DISCUSSÃO}

\subsection{Morfometria do relevo}

Tendo por base a planialtimetria, identificaram-se dois padrões para as curvas de nível: um com curvas próximas, estreitas e circundantes à rede de drenagem, e altitude variando entre 775 e $800 \mathrm{~m}$; outro, com curvas espaçadas, presentes no restante da área (Figura 6).

A altitude foi subdividida em cinco classes, variando de 750 a 863 m (Tabela 2 e Figura 7). A maior parte da área, $40 \%$, tem altitude que varia entre 800 e $825 \mathrm{~m}$. Considerando a amplitude de altitude, $113 \mathrm{~m}$, o relevo predominantemente é o suave ondulado (declividade média entre 2 e 10\%), com 65\% da área; $21 \%$ é ondulado (Tabela 3 e Figura 8). As maiores ramificações da rede de drenagem são encontradas em áreas de menor altitude, devido à sobrecarga de água proveniente de partes mais elevadas; as áreas de relevo ondulado (>10\%) antecedem os canais de drenagem.

Tabela 2. Distribuição das classes hipsométricas na E.E. de Itatinga

\begin{tabular}{cccc}
\hline & & \multicolumn{2}{c}{ Área } \\
Classe & Altitude & Absoluta & Relativa \\
\hline & $m$ & ha & $\%$ \\
2 & $750-775$ & 164 & 8 \\
3 & $775-800$ & 430 & 21 \\
4 & $800-825$ & 819 & 40 \\
\hline
\end{tabular}




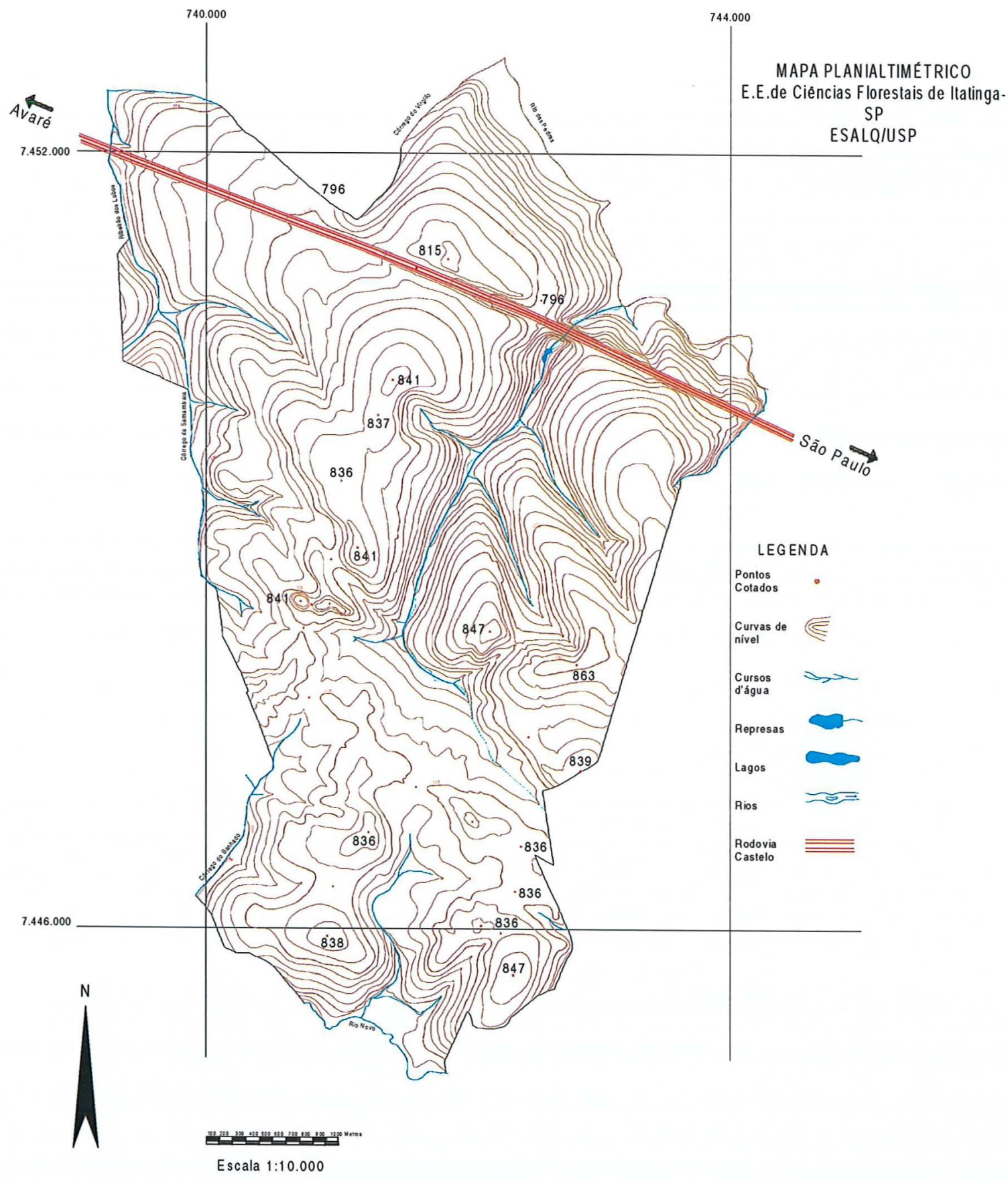

Figura 6 - Mapa planialtimétrico da E.E. de Itatinga. 


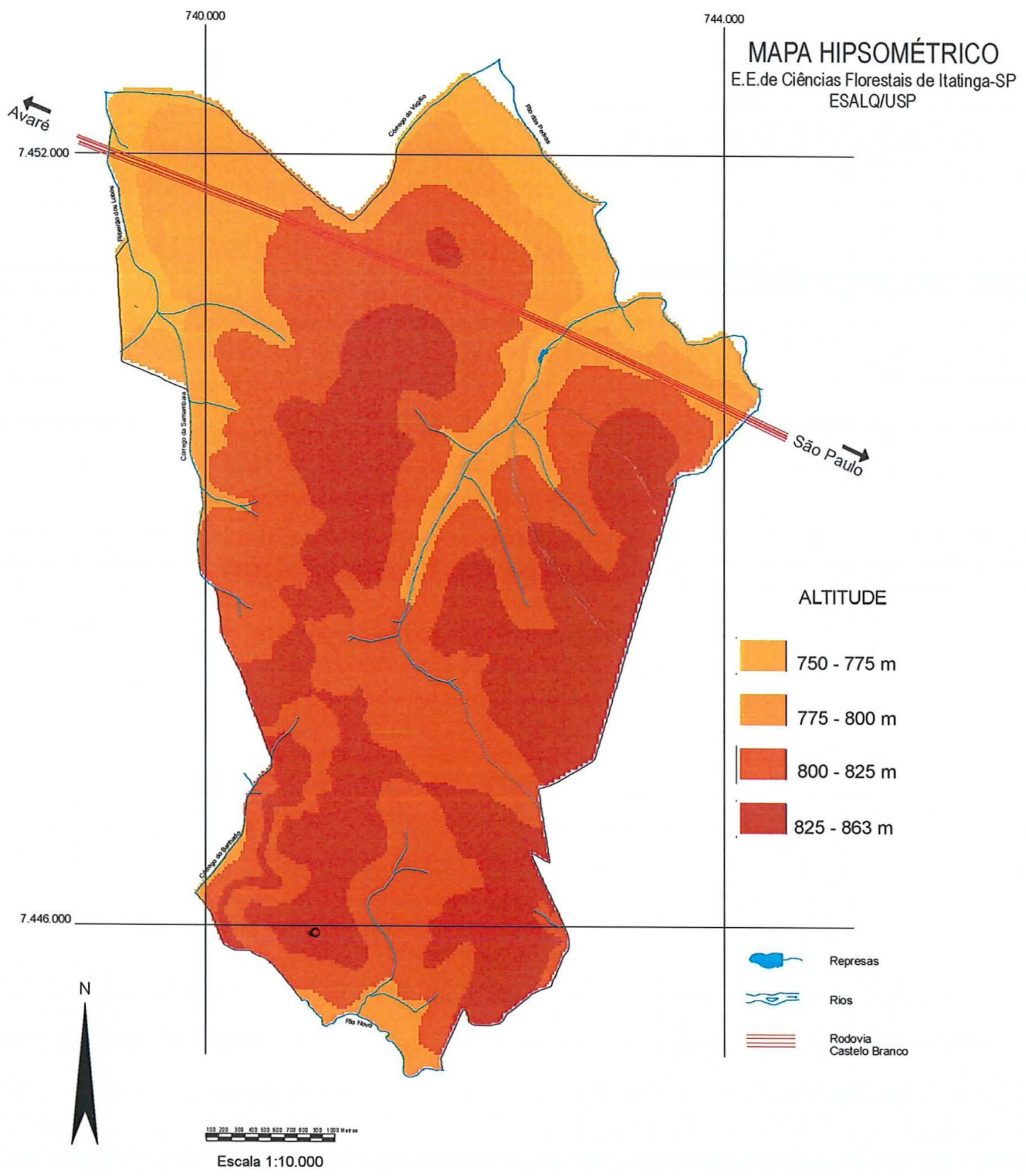

Figura 7 - Mapa de classes de altitude da E.E. de Itatinga. 


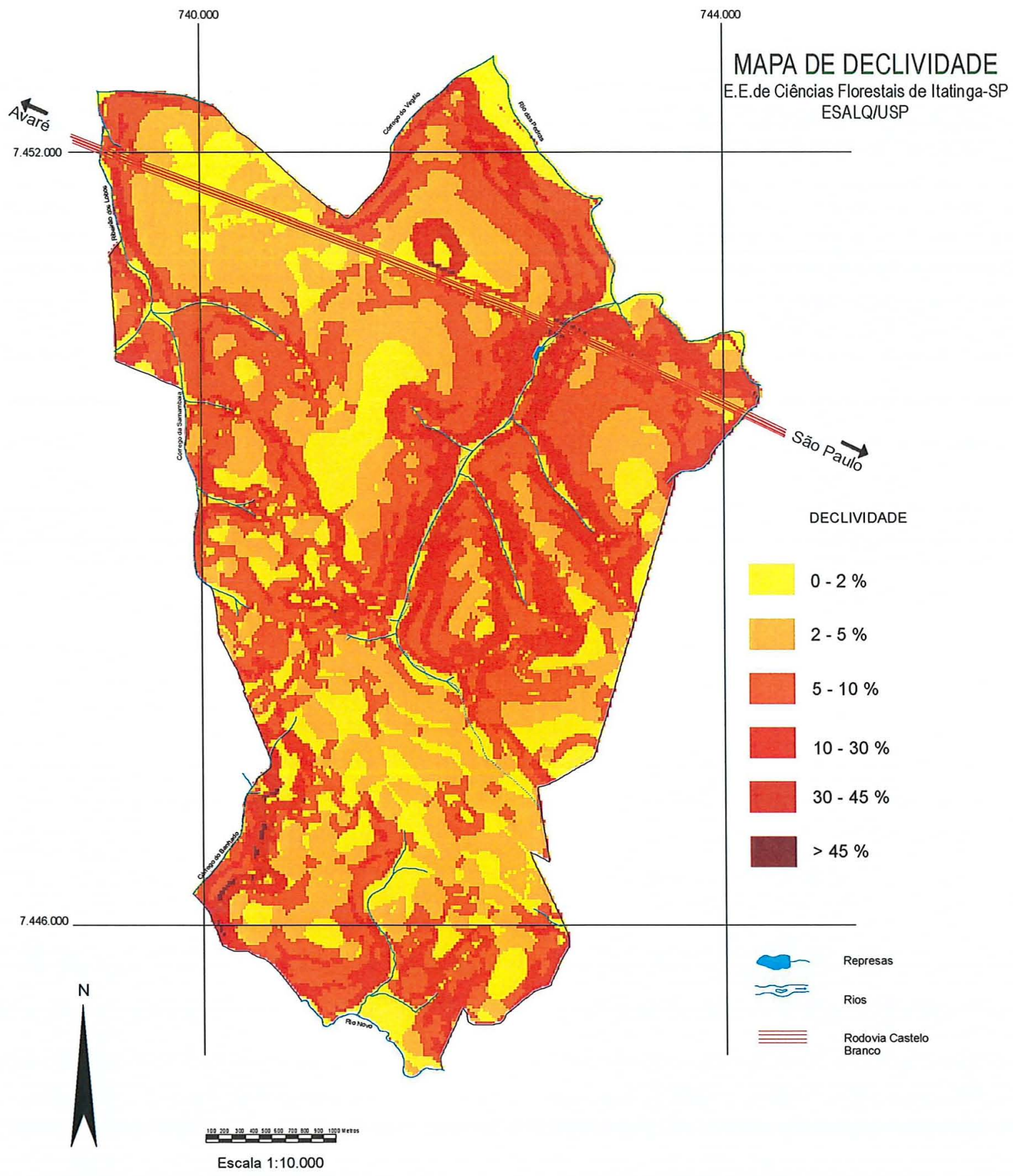

Figura 8 - Mapa de classes de declividade da E.E. de Itatinga. 
Tabela 3. Distribuição das classes de declividade na E.E. de Itatinga

\begin{tabular}{ccccc}
\hline Classe & Classe & Clinografia & \multicolumn{2}{c}{ Área } \\
& & & Absoluta & Relativa \\
\hline & $\%$ & graus & ha & $\%$ \\
2 & $0-2$ & $0-0,9$ & 287 & 14 \\
3 & $2-5$ & $0,09-2,25$ & 654 & 32 \\
4 & $5-10$ & $2,25-4,5$ & 675 & 33 \\
5 & $10-30$ & $4,5-13,5$ & 389 & 19 \\
6 & $30-45$ & $13,5-20,5$ & 41 & 2 \\
& $>45$ & $>20,25$ & 1 & 0,08 \\
\hline
\end{tabular}

\subsection{Mapa detalhado de solos}

Foram encontradas cinco classes de solos $-4^{\circ}$ nível categórico: Latossolo Vermelho-Amarelo Distrófico típico A moderado textura média, LVAd1 e LVAd2, com 1003 ha no total $(49 \%)$, Latossolo Vermelho Distrófico típico A moderado textura argilosa e média, LVd, com 696 ha (34\%), Latossolo Vermelho Distroférrico típico A moderado textura argilosa, LVdf, com 225 ha (11\%), Gleissolos, G, com 102 ha (5\%) e Neossolo Flúvico, $\mathrm{RU}$, com 21 ha (1\%) conforme mostra a Tabela 4.

O LVAd e o LVd foram formados a partir da intemperização de arenito, Grupo Bauru, Formação Marília e, o LVdf, a partir de basalto, do Grupo São Bento, Formação Serra Geral (IPT, 1984). Espíndola \& Garcia (1978) discutem a proximidade de materiais de origem distintos, o que proporciona uma mistura na constituição do material original dos solos e dificulta a identificação e delimitação das unidades pedológicas. Nesta pesquisa, constatou-se essa dificuldade, em especial para o LVdf e o LVd, pois quanto mais próximo da formação basáltica, maior a proporção de óxidos de ferro encontrados. Constatou-se que o LVd apresenta maiores variações de relevo e o LVdf condições texturais mais finas. 
Tabela 4. Classificação taxonômica dos solos da E.E. Itatinga

\begin{tabular}{|c|c|c|c|}
\hline \multirow[b]{2}{*}{ Símbolo } & \multirow[b]{2}{*}{ Classificação } & \multicolumn{2}{|c|}{ Área } \\
\hline & & Absoluta & Relativa \\
\hline & & ha & $\%$ \\
\hline LVAd & $\begin{array}{l}\text { Latossolo Vermelho-Amarelo Distrófico típico A } \\
\text { moderado textura média }\end{array}$ & 1003 & 49 \\
\hline LVd & $\begin{array}{l}\text { Latossolo Vermelho Distrófico típico A moderado } \\
\text { textura argilosa e média }\end{array}$ & 696 & 34 \\
\hline LVdf & $\begin{array}{l}\text { Latossolo Vermelho Distroférrico típico A moderado } \\
\text { textura argilosa }\end{array}$ & 225 & 11 \\
\hline G & Gleissolo & 102 & 5 \\
\hline RU & Neossolos Flúvico & 21 & 1 \\
\hline Total & & 2047 & 100 \\
\hline
\end{tabular}

Descrição dos solos

\section{Latossolo Vermelho-Amarelo Distrófico típico A moderado textura média}

Ocorre em altitudes acima de $800 \mathrm{~m}$, em relevo suave ondulado. Este solo está associado à formação arenítica TQcv (Figura 9 e 10). Grande parte da área está ocupada com plantios comerciais e experimentais de eucalipto. A profundidade do horizonte $A$ varia entre 15 e $35 \mathrm{~cm}$ de espessura, o matiz varia de 7,5 YR 5/4 - 4/2 a 5 YR 3/4, apresentando baixa plasticidade e pegajosidade. O horizonte B1 apresenta, em média, $30 \mathrm{~cm}$ de espessura; matiz que varia entre $5 Y R 4 / 6$ a $5 Y R 4 / 4$, apresenta fraca cerosidade, estrutura granular e blocos subangulares. Amostras a seco apresentam dureza média e, quando úmida, friável (Tabela 5). A nitidez de contraste entre os horizontes $\mathrm{A}$ e Bw é evidente, principalmente, pela cor e características estruturais. O horizonte $\mathrm{Bw}$ é característico, com constituintes em avançado estágio de intemperização e diferenciação difusa entre subhorizontes. A drenagem é boa. 
Tabela 5. Descrição morfológica dos latossolos na E.E. de Itatinga

\begin{tabular}{|c|c|c|c|c|c|c|c|c|c|c|c|}
\hline \multirow[t]{2}{*}{ Horiz. } & \multirow{2}{*}{$\begin{array}{l}\text { Prof. } \\
\mathrm{cm}\end{array}$} & \multirow{2}{*}{$\begin{array}{l}\text { Cor } \\
\text { Ümida }\end{array}$} & \multirow{2}{*}{$\begin{array}{l}\text { Classe } \\
\text { Textural }\end{array}$} & \multicolumn{2}{|c|}{ Estrutura $^{(1)}$} & \multirow[t]{2}{*}{ Ceros. $^{(2)}$} & \multirow{2}{*}{$\begin{array}{l}\text { Consist. } \\
\text { Úmida }^{(3)}\end{array}$} & \multirow[t]{2}{*}{ Pegaj. $^{(4)}$} & \multirow[t]{2}{*}{ Trans. $^{(5)}$} & \multicolumn{2}{|c|}{ Raízes $^{(6)}$} \\
\hline & & & & Tipo & Tamanho & & & & & Tipo & Quant. \\
\hline \multicolumn{12}{|c|}{ LVAd1 - Latossolo Vermelho-Amarelo Distrófico textura arenosa } \\
\hline \multirow[t]{2}{*}{41} & $0-20$ & 7,5 YR $5 / 4$ & Arenosa & GR & $P$ & 0 & $\mathrm{~S}$ & $\mathrm{NPe}$ & o-gradual & $f$ & rpp \\
\hline & & $5,0 Y R 3 / 4$ & & & & & & & & & \\
\hline \multirow[t]{2}{*}{$3 w$} & $70-90$ & $5,0 Y R 4 / 6$ & Arenosa & GR & $P$ & 1 & $S$ & $\mathrm{NPe}$ & o-difusa & $f$ & rc \\
\hline & & 5,0 YR $4 / 4$ & & & & & & & & & \\
\hline \multicolumn{12}{|c|}{ LVAd2 - Latossolo Vermelho-Amarelo Distrófico textura média } \\
\hline \multirow[t]{2}{*}{41} & $0-20$ & $7,5 Y R 5 / 4$ & Média & GR & $P$ & 0 & $S$ & $\mathrm{NPe}$ & o-gradual & $f$ & rpp \\
\hline & & 5,0 YR $3 / 4$ & & & & & & & & & \\
\hline \multirow[t]{3}{*}{$3 w$} & $70-90$ & 5,0 YR $4 / 6$ & Média & GR & $P$ & 1 & $S$ & $\mathrm{NPe}$ & o-difusa & $f$ & rc \\
\hline & & 5,0 YR $4 / 4$ & & & & & & & & & \\
\hline & \multicolumn{10}{|c|}{ LVd - Latossolo Vermelho Distrófico típico A moderado textura argilosa e média } & \\
\hline 41 & $0-20$ & 5,0 YR $3 / 3$ & Média & BA/BS & M & 2 & $F$ & LP & o-gradual & $f$ & rpp \\
\hline $3 w$ & $70-90$ & $2,5 Y R 3 / 4$ & Média & $\mathrm{BA} / \mathrm{BS}$ & $\mathrm{M} / \mathrm{P}$ & 2 & $\bar{F}$ & $\mathrm{Pe}$ & o-difusa & $f$ & rpp \\
\hline \multicolumn{12}{|c|}{ LVdf - Latossolo Distroférrico típico A moderado textura argilosa } \\
\hline 41 & $0-20$ & $2,5 Y R 3 / 4$ & Argilosa & GR/BS & $\mathrm{P}$ & 3 & $\bar{F}$ & $\mathrm{Pe}$ & o-gradual & $f$ & rpp \\
\hline$B w$ & $70-90$ & $2,5 \mathrm{YR} 3 / 6$ & Argilosa & GR/BS & $P$ & 3 & $\overline{\mathrm{F}}$ & $\mathrm{Pe}$ & o-difusa & $f$ & $\mathrm{rpp}$ \\
\hline
\end{tabular}

(1)Tipo - GR:granular, BA: blocos angulares, BS: blocos subangulares; Tamanho - P: pequeno, $\quad$ M: médio. (2) Cerosidade - 0: ausente, 1: fraca, 2: moderada; 3: forte. (3) Consistência Úmida - $\quad S$ : solto, $F:$ friável, $\bar{F}$ : muito friável. (4) Pegajosidade - NPe: não pegajoso, LP: ligeiramente pegajoso, Pe: pegajoso. (5) Transição entre horizontes - o: ondulada. (6) Raízes - rpp: maior proporção, rc: comuns. 
Na camada $A 1$, há predomínio de textura arenosa e, ou, franco-arenosa, variando entre 810 e $880 \mathrm{~g} \mathrm{Kg}^{-1}$ de areia e 100 a $160 \mathrm{~g} \mathrm{Kg}^{-1}$ de argila; os teores de silte são muito baixos, com variação entre 10 e $50 \mathrm{~g} \mathrm{Kg}^{-1}$; a relação silte/argila é baixa, com valores inferiores a 0,7. O horizonte Bw apresenta, também, textura arenosa e, ou, franco-arenosa, com variação entre 780 e $850 \mathrm{~g} \mathrm{Kg}^{-1}$ de areia e 120 e $200 \mathrm{~g} \mathrm{Kg}^{-1}$ de argila; a relação silte/ argila é baixa, com valores inferiores a 0,3 . O incremento de argila do horizonte A para o Bw é baixo, variando entre 1 e 1,5. Os perfis representativos, 3 e 4 estão descritos na Tabela 6.

Tabela 6 . Análises físicas de alguns perfis representativos

\begin{tabular}{|c|c|c|c|c|c|c|c|c|c|c|}
\hline \multirow{3}{*}{$\begin{array}{c}\text { Amostra } \\
\text { Identificação }\end{array}$} & Horiz. & Prof. & \multicolumn{4}{|c|}{ Granulometria } & \multirow[t]{3}{*}{ Silte/Argila } & \multirow{3}{*}{\multicolumn{2}{|c|}{ 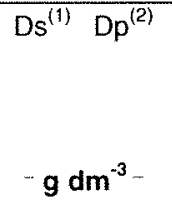 }} & \multirow{3}{*}{$\begin{array}{c}\text { Porosidade } \\
\%\end{array}$} \\
\hline & & & \multirow[t]{2}{*}{ Argila } & \multirow[t]{2}{*}{ Silte } & $\begin{array}{c}\text { Areia } \\
\text { grossa }\end{array}$ & \multirow{2}{*}{$\begin{array}{c}\text { Areia } \\
\text { fina }\end{array}$} & & & & \\
\hline & & $\mathrm{cm}$ & & & $\mathbf{g ~ k g}^{-1}$ & & & & & \\
\hline \multicolumn{11}{|c|}{ LVAd1 - Latossolo Vermelho-Amarelo Distrófico textura arenosa } \\
\hline P-4 & $A 1$ & $0-20$ & 160 & 20 & 580 & 240 & 0,13 & 1,39 & 2,06 & 33 \\
\hline P-4 & Bw & $70-90$ & 240 & 40 & 460 & 260 & 0,17 & 1,35 & 2,11 & 34 \\
\hline P-3 & $A 1$ & $0-20$ & 60 & 30 & 460 & 450 & 0,50 & 1,34 & 2,11 & 23 \\
\hline P-3 & Bw & $70-90$ & 240 & 40 & 340 & 380 & 0,17 & 1,35 & 2,22 & 36 \\
\hline \multicolumn{11}{|c|}{ LVAd2 - Latossolo Vermelho-Amarelo Distrófico textura média } \\
\hline P-4 & A1 & $0-20$ & 160 & 20 & 580 & 240 & 0,13 & 1,39 & 2,06 & 33 \\
\hline P-4 & Bw & $70-90$ & 240 & 40 & 460 & 260 & 0,17 & 1,35 & 2,11 & 34 \\
\hline P-3 & At & $0-20$ & 60 & 30 & 460 & 450 & 0,50 & 1,34 & 2,11 & 23 \\
\hline P-3 & $\mathrm{Bw}$ & $70-90$ & 240 & 40 & 340 & 380 & 0,17 & 1,35 & 2,22 & 36 \\
\hline \multicolumn{11}{|c|}{ LVd - Latossolo Vermelho Distrófico típico A moderado textura argilosa e média } \\
\hline$T-6$ & A1 & $0-20$ & 320 & 60 & 240 & 380 & 0,19 & 1,39 & 2,13 & 35 \\
\hline$T-6$ & $\mathrm{Bw}$ & $70-90$ & 340 & 80 & 230 & 350 & 0,24 & 1,23 & 2,35 & 48 \\
\hline $\mathrm{T}-2$ & A1 & $0-20$ & 290 & 40 & 250 & 420 & 0,14 & - & - & - \\
\hline $\mathrm{T}-2$ & $\mathrm{Bw}$ & $70-90$ & 360 & 60 & 200 & 380 & 0,17 & - & - & - \\
\hline \multicolumn{11}{|c|}{ LVdf - Latossolo Distroférrico típico A moderado textura argilosa } \\
\hline $\mathrm{G}-1$ & A1 & $0-20$ & 550 & 120 & 330 & - & 0,22 & - & - & - \\
\hline $\mathrm{G}-1$ & $B w$ & $70-90$ & 630 & 70 & 300 & - & 0,11 & - & - & - \\
\hline G-3 & $\mathrm{A} 1$ & $0-20$ & 560 & 180 & 360 & $\cdot$ & 0,32 & - & - & - \\
\hline G-3 & $B w$ & $70-90$ & 660 & 140 & 200 & - & 0,21 & - & - & - \\
\hline
\end{tabular}

Obs.: Horiz.: horizonte; prof.: profundidade; Ds: densidade do solo; Dp.: densidade de partículas 
Todos os solos são distróficos, com baixos teores de matéria orgânica, alto índice de acidez, caráter alumínico (horizontes $A$ e Bw), com variação entre 11 e $21 \mathrm{mmol}_{\mathrm{c}} \mathrm{Kg}^{-1} \mathrm{de}$ aluminio, baixa saturação por bases $(V \leq 50 \%)$, em especial no horizonte $B$, além de baixa capacidade de troca catiônica (CTC). Os perfis representativos dessas características, 3 e 4 estão apresentados na Tabela 7.

Tabela 7. Análises químicas de alguns perfis representativos

\begin{tabular}{|c|c|c|c|c|c|c|c|c|c|c|c|c|c|}
\hline \multirow{2}{*}{$\begin{array}{c}\text { Amostras } \\
\text { Identificação }\end{array}$} & \multirow[t]{2}{*}{ Horiz. } & \multirow[t]{2}{*}{ Prof. } & \multirow[t]{2}{*}{ M.O. } & \multicolumn{2}{|c|}{$\mathrm{pH}$} & \multirow{2}{*}{$\begin{array}{c}\Delta \\
\mathrm{pH}\end{array}$} & \multirow[t]{2}{*}{ P-resina } & \multicolumn{5}{|c|}{ Cátions Trocáveis } & \multirow[t]{2}{*}{ CTCe } \\
\hline & & & & \multirow[t]{2}{*}{$\mathrm{KCl}$} & \multirow{2}{*}{\multicolumn{2}{|c|}{$\mathrm{H}_{2} \mathrm{O}$}} & & \multirow[t]{2}{*}{$\mathrm{Ca}$} & \multirow[t]{2}{*}{$\mathrm{Mg}$} & \multirow{2}{*}{\multicolumn{3}{|c|}{$\begin{array}{ll}K & H \quad A l \\
\mathbf{m m o l}_{\mathbf{c}} \mathbf{K g}^{-1}\end{array}$}} & \\
\hline & $\mathrm{cm}$ & $\mathrm{g} \mathrm{Kg}^{-1}$ & & & & & $\mathrm{mg} \mathrm{Kg}^{-1}$ & & & & & & \\
\hline \multicolumn{14}{|c|}{ LVAd1 - Latossolo Vermelho-Amarelo Distrófico textura arenosa } \\
\hline$P-4$ & $\mathrm{~A} 1$ & $0-20$ & 34 & 3,4 & 3,6 & $-0,2$ & 3 & 1 & 1 & 0,5 & 76 & 22 & 101 \\
\hline P-4 & Bw & $70-90$ & 13 & 4,0 & 4,2 & $-0,2$ & 2 & 1 & 1 & 0,7 & 26 & 6 & 37 \\
\hline P-3 & A1 & $0-20$ & 16 & 3,8 & 3,8 & 0 & 2 & 1 & 1 & 0,2 & 20 & 8 & 30 \\
\hline$P-3$ & Bw & $70-90$ & 12 & 4,3 & 4,3 & 0 & 1 & 1 & 1 & 0,2 & 4 & 24 & 30 \\
\hline \multicolumn{14}{|c|}{ LVAd2 - Latossolo Vermelho-Amarelo Distrófico textura média } \\
\hline P-4 & A1 & $0-20$ & 34 & 3,4 & 3,6 & $-0,2$ & 3 & 1 & 1 & 0,5 & 76 & 22 & 101 \\
\hline P-4 & $\mathrm{Bw}$ & $70-90$ & 13 & 4,0 & 4,2 & $-0,2$ & 2 & 1 & 1 & 0,7 & 26 & 6 & 37 \\
\hline P-3 & $A 1$ & $0-20$ & 16 & 3,8 & 3,8 & 0 & 2 & 1 & 1 & 0,2 & 20 & 8 & 30 \\
\hline P-3 & $\mathrm{Bw}$ & $70-90$ & 12 & 4,3 & 4,3 & 0 & 1 & 1 & 1 & 0,2 & 4 & 24 & 30 \\
\hline \multicolumn{14}{|c|}{ LVd - Latossolo Vermelho Distrófico típico A moderado textura argilosa e média } \\
\hline T-6 & A1 & $0-20$ & 24 & 3,8 & 4,0 & $-0,2$ & 0,2 & 1 & 1 & 0,5 & 54 & 18 & 75 \\
\hline T-6 & Bw & $70-90$ & 17 & 3,9 & 4,1 & $-0,2$ & 0,2 & 2 & 1 & 0,8 & 30 & 12 & 46 \\
\hline$T-2$ & A1 & $0-20$ & 22 & 3,4 & 3,8 & $-0,4$ & 0,4 & 1 & 1 & 0,4 & 44 & 20 & 66 \\
\hline $\mathrm{T}-2$ & $B w$ & $70-90$ & 12 & 3,1 & 3,7 & $-0,6$ & 0,4 & 1 & 1 & 0,2 & 41 & 17 & 60 \\
\hline \multicolumn{14}{|c|}{ LVdf - Latossolo Distroférrico típico A moderado textura argilosa } \\
\hline G-1 & A1 & $0-20$ & 33 & 4,3 & - & $\cdot$ & 9 & 19 & 10 & 3,2 & 70 & 8 & 40 \\
\hline G-1 & Bw & $70-90$ & 12 & 4,2 & - & - & 5 & 3 & 1 & 1,3 & 36 & 2 & 7 \\
\hline G-3 & A1 & $0-20$ & 38 & 4,4 & - & . & 5 & 21 & 11 & 1,4 & 72 & 6 & 39 \\
\hline G-3 & Bw & $70-90$ & 19 & 4,4 & - & - & 5 & 8 & 4 & 0,4 & 47 & 5 & 17 \\
\hline
\end{tabular}




\section{Latossolo Vermelho Distrófico típico A moderado textura argilosa e média}

O LVd está localizado em altitudes que variam entre 775 e $800 \mathrm{~m}$, em relevo ondulado e declividade entre 10 e $30 \%$ (Figuras 8 e 10). Parte da área está coberta com plantações de eucalipto. A profundidade do horizonte A1 varia entre 20 e $25 \mathrm{~cm}$ de espessura, o matiz varia entre 5 YR 3/3 - 4/4 e 2,5 YR 3/4; a consistência é ligeiramente pegajosa. A transição entre os horizontes $\mathrm{A}$ e Bw é ondulada e gradual, evidenciada principalmente pela cor. O horizonte Bw é característico, em avançado estágio de intemperização e diferenciação difusa entre os subhorizontes. O Bw1 apresenta, em média, $60 \mathrm{~cm}$ de espessura; matiz 2,5 YR 3/6, moderada cerosidade, alta plasticidade e pegajosidade, estrutura granular e blocos subangulares. As amostras a seco apresentaram dureza média e, quando úmida, muito friável (Tabela 5). A drenagem é boa. Na camada A1, há predomínio de textura média arenosa variando entre 660 e $860 \mathrm{~g} \mathrm{Kg}^{-1}$ de areia; os teores de silte são baixos, variando entre 10 e $40 \mathrm{~g} \mathrm{Kg}^{-1}$. O horizonte $\mathrm{Bw}$ apresenta, também, textura média arenosa, variando entre 580 e $770 \mathrm{~g} \mathrm{Kg}^{-1}$ de areia; os teores de silte são baixos, variando entre 10 e $150 \mathrm{~g} \mathrm{Kg}^{-1}$; nas duas profundidades, as relações silte/argila são inferiores a 0,4; caráter ácrico dentro de $150 \mathrm{~cm}$ da superfície do solo. As análises químicas apresentaram baixa saturação por bases, caráter alumínico e baixa CTC.

\section{Latossolo Distroférrico típico A moderado textura argilosa}

O LVdf ocorre nas áreas mais declivosas, próximas à rede de drenagem (Figuras 8 e 10). Ao relacionar o mapa de solos com o mapa hipsométrico, observa-se que o LVdf está localizado nas menores altitudes, entre 750 e 775 m; quanto à declividade, pode-se constatar que predomina entre 10 e $15 \%$, e entre $15-30 \%$, o que caracteriza um relevo ondulado. O horizonte A é espesso, com mais de $30 \mathrm{~cm}$, matiz 2,5YR $3 / 4$, alta plasticidade e pegajosidade. A transição entre os horizontes A e Bw é difusa e gradual, evidenciada unicamente pela cor. O horizonte $\mathrm{Bw}$ apresenta matiz 2,5YR 3/6, textura argilosa ou muito argilosa (Tabela 5). Na camada A1, há predomínio da textura argilosa, com variação entre 100 e $650 \mathrm{Kg}^{-1}$ de argila e 180 e $770 \mathrm{Kg}^{-1}$ de areia. Os teores de silte são baixos, variação entre 70 e $180 \mathrm{Kg}^{-1}$. A relação entre silte/argila é baixa nos dois horizontes e, o incremento de argila do horizonte $\mathrm{A} 1$ para o $\mathrm{Bw}$ também é baixo. No horizonte $\mathrm{B}, \mathrm{o}$ teor 
de argila varia de 200 a $730 \mathrm{~g} \mathrm{Kg}^{-1}$ (Tabela 6). Estes solos apresentam teores de carbono orgânico acima de 1\%, baixa concentração de fósforo, matéria orgânica e bases trocáveis (Tabela 7). A área de abrangência do LVdf tem relação direta com a área de ocorrência de basalto (Figuras 9 e 10).

\section{Neossolos Flúvicos}

São solos aluviais, derivados de sedimentos aluviais, com horizonte A sobre horizonte $C$, constituido de camadas estratificadas, sem relação pedogenética entre si (EMBRAPA, 1999). Estão presentes no limite norte, à direita da propriedade, antecedendo o Rio das Pedras, a $750 \mathrm{~m}$ de altitude (Figuras 6 e 10). Por estarem em área de preservação permanente, sem possibilidade de uso silvicultural, foram apenas identificadas e delimitadas.

\section{Gleissolos}

São constituídos por material com horizonte glei, imediatamente abaixo de horizonte A, ou de horizonte hístico com menos de $40 \mathrm{~cm}$ de espessura; ou horizonte glei começando dentro de $50 \mathrm{~cm}$ da superfície do solo (Embrapa, 1999). Ocupam as posições baixas ao longo dos cursos d'água (Figura 6 e 10). Por estarem em área de preservação permanente, sem possibilidade de uso silvicultural, foram apenas identificadas e delimitadas.

\subsection{Relação produtividade vs. solo}

As classes de produtividade, aos 6 anos de idade, baseadas no Incremento Médio Anual (IMA) do volume sólido de madeira com casca, na área arrendada, foram agrupadas em seis classes: I, de 77 a $69 \mathrm{Stc} / \mathrm{c} \mathrm{ha}^{-1}$ ano-1 $^{-1}$, produtividade muito alta; II, de 68 a $62 \mathrm{Stc} / \mathrm{c}$ ha-1 ano-1, produtividade alta; III, de 61 a $54 \mathrm{Stc} / \mathrm{c} \mathrm{ha}^{-1}$ ano-1 $^{-1}$, produtividade média; IV, de 53 a $47 \mathrm{Stc} / \mathrm{c}$ ha-1 ano $^{-1}$, produtividade baixa; $\mathrm{V}$, de 46 a $40 \mathrm{Stc} / \mathrm{c} \mathrm{ha}^{-1}$ ano-1, produtividade muito baixa; e a VI, de 39 a $32 \mathrm{Stc} / \mathrm{c} \mathrm{ha}^{-1}$ ano-1 $^{-1}$, produtividade extremamente baixa (Figura 11). 


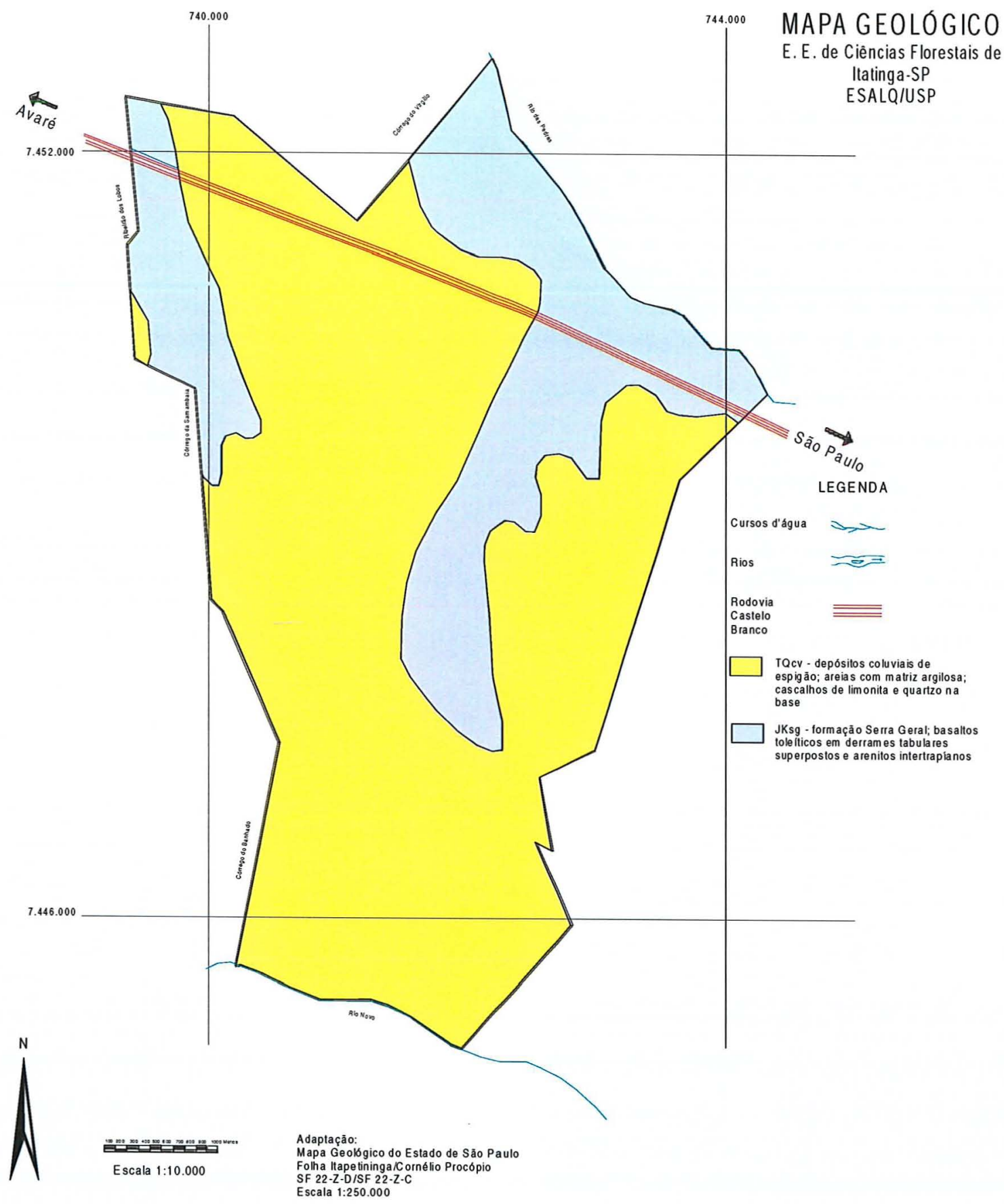

Figura 9 - Mapa geológico (IPT, 1984) da E.E. de Itatinga. O LVdf ocorre em formação JKsg, e os LVd-1 e LVd-2 ocorrem na formação TQcv. 


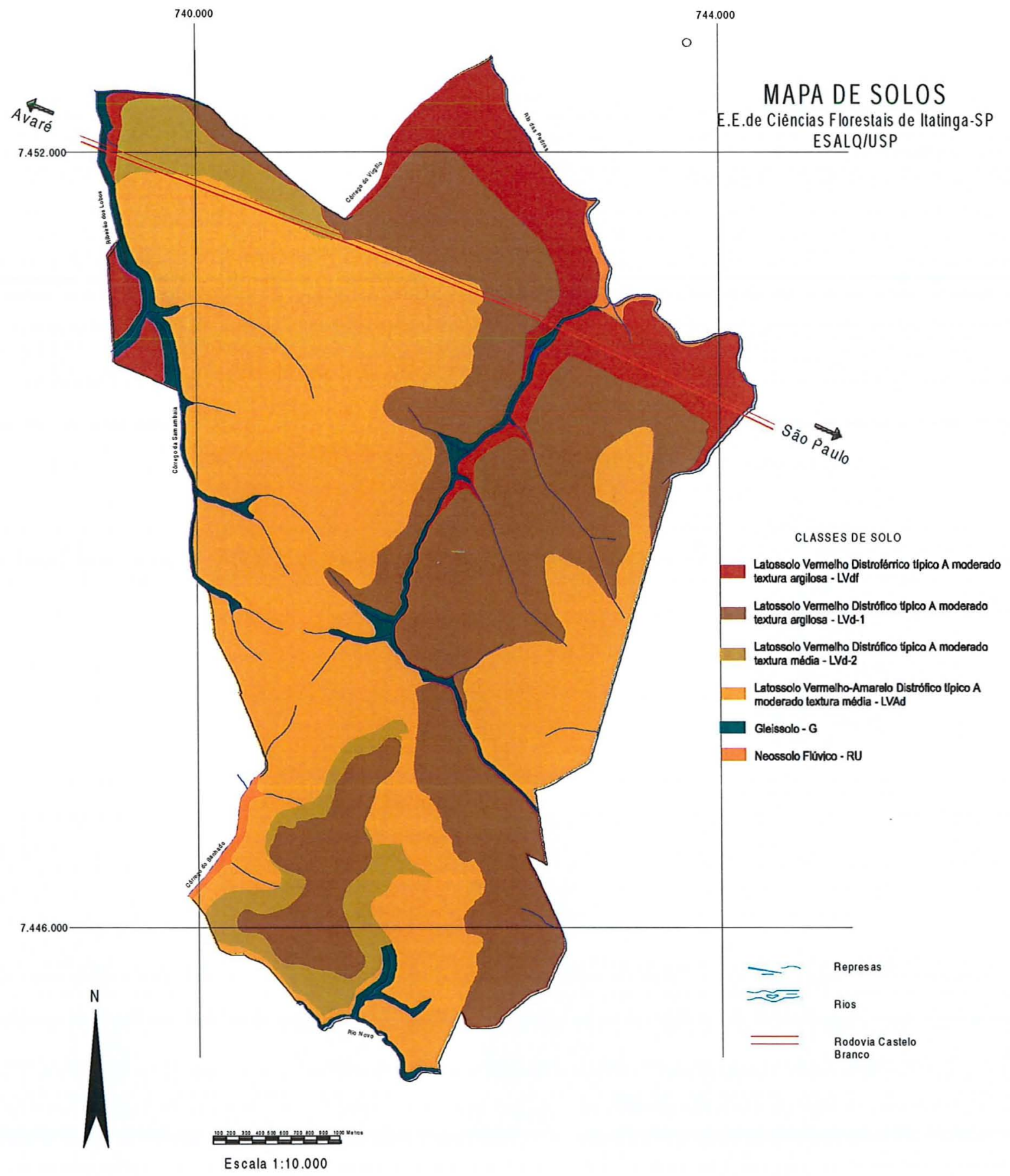

Figura 10 - Mapa detalhado de solos da E.E. de Itatinga. 


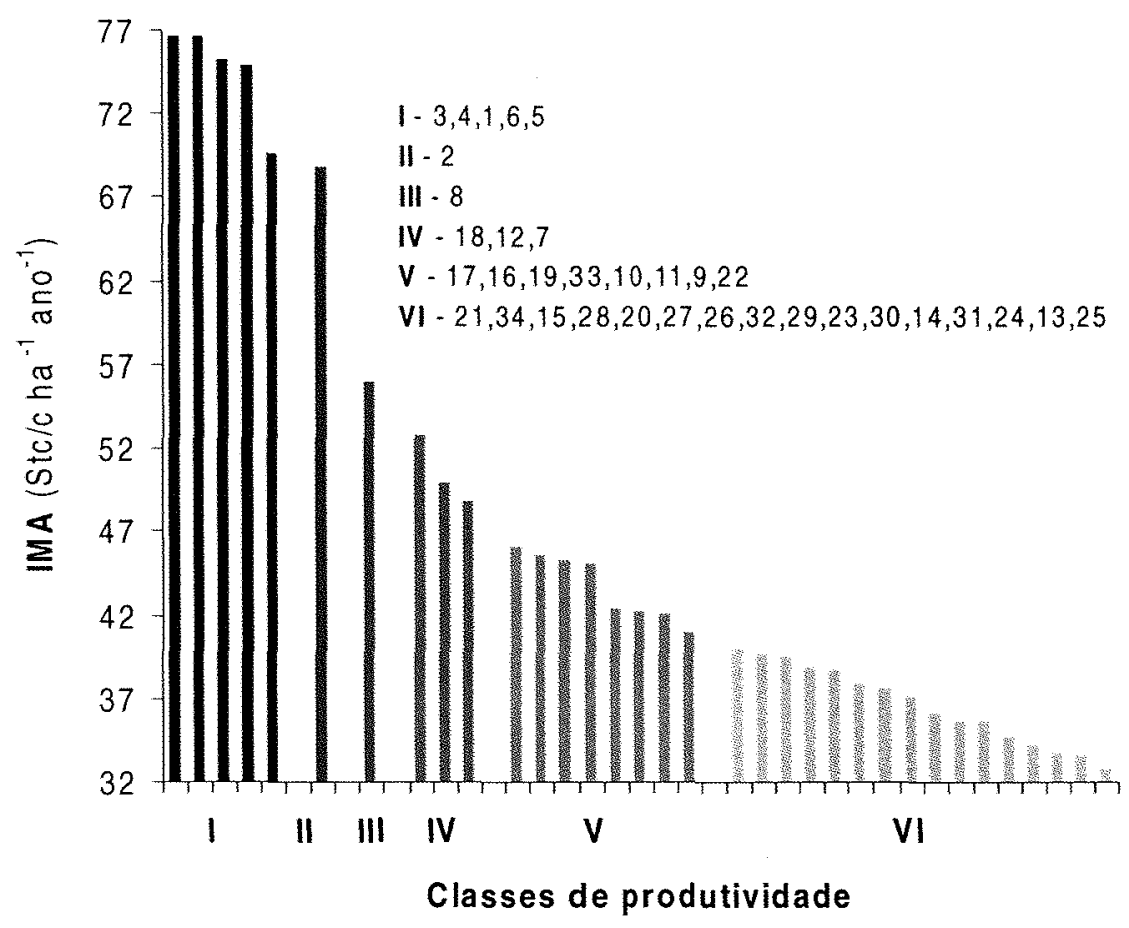

Figura 11 - Classes de produtividade, baseadas no IMA (em Stc/c ha-1 ano-1): I, 77 a 69; II, 68 a 62; III, 61 a $54 ;$ IV, 53 a 47 ; V, 46 a 40 e VI, 39 a 32.

A espacialização das informações obtida com a classificação da produtividade possibilitou constatar a relação direta dessa produtividade com as classes de solos. Os talhões com mesma unidade pedológica estavam também, dentro da mesma classe de produtividade; a classe I (produtividade muito alta), por exemplo, é caracterizada pela presença do LVdf, o solo mais produtivo da E.E. de Itatinga (Figura 12) . 


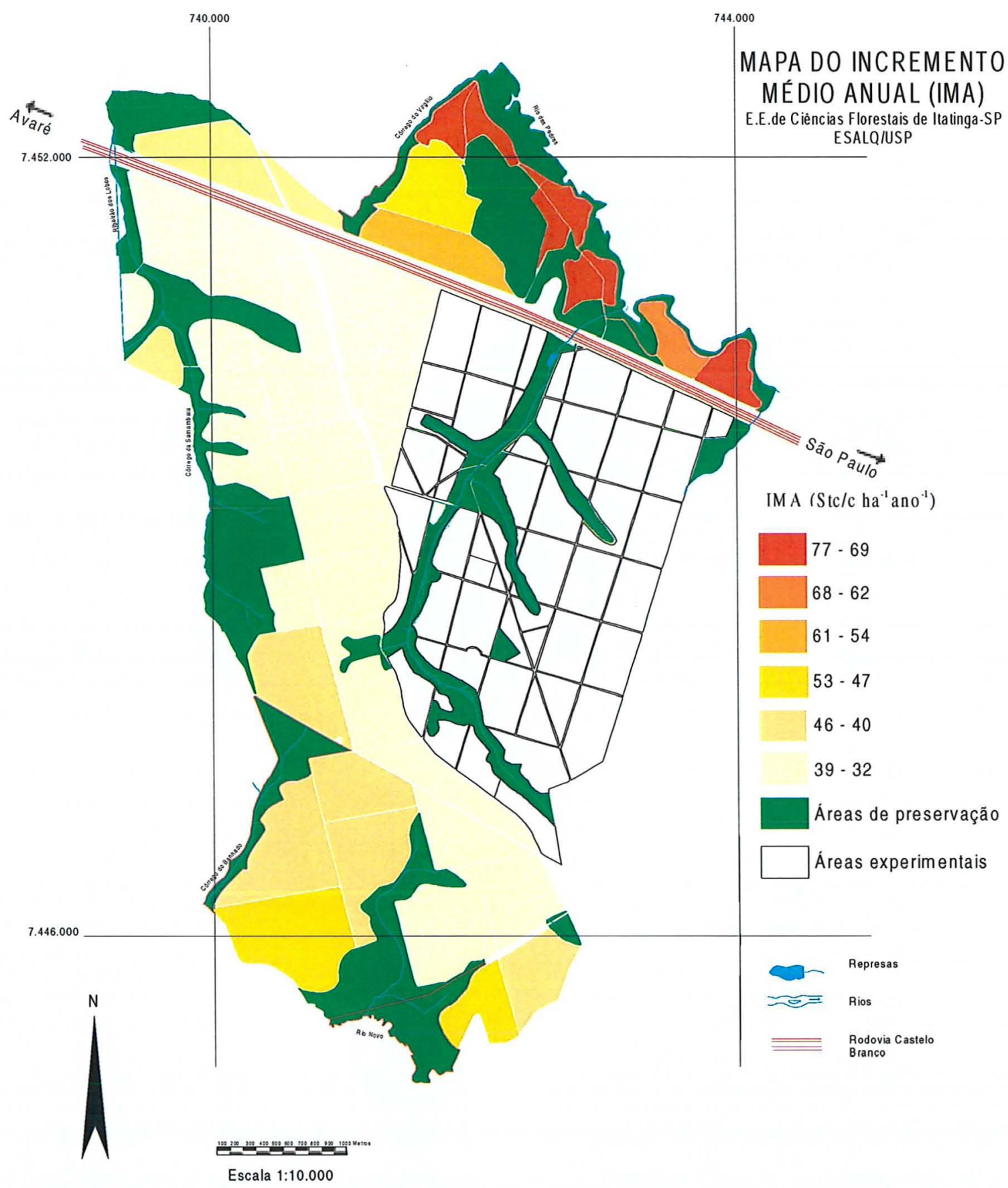

Figura 12 - Mapa do Incremento Médio Anual (IMA), aos 6 anos de idade, na E.E. de Itatinga. 
O IMA apresentou altas correlações $(>0,70)$ com os teores de argila, matéria orgânica (MO), $\mathrm{Ca}, \mathrm{Mg}$, pH e a CTCe na camada 0-20 cm de solo; menores correlações, embora significativas, foram observadas na camada $70-90 \mathrm{~cm}$ (Tabela 8). Apenas o teor de areia correlacionou-se negativamente com o IMA. Observou-se que as variações dessas variáveis foram altas entre os solos, por exemplo, na camada $0-20 \mathrm{~cm}$, a amplitude de variação do teor de argila foi de 0 a $650 \mathrm{~g} \mathrm{~kg}^{-1}$; de 8 a $38 \mathrm{~g} \mathrm{~kg}^{-1}$ para a MO; 0 a $21 \mathrm{mmol}_{\mathrm{c}}$ $\mathrm{dm}^{-3}$ para o Ca; 0 a $11 \mathrm{mmol}_{\mathrm{c}} \mathrm{dm}^{-3}$ para o $\mathrm{Mg} ; 3,5$ a 4,4 para o $\mathrm{pH}$; e 11 a $40 \mathrm{mmol}_{\mathrm{c}} \mathrm{dm}^{-3}$ para a CTCe. O horizonte $\mathrm{Bw}$, na camada $70-90 \mathrm{~cm}$, apresenta amplitude de variação do teor de argila entre 120 a $730 \mathrm{~g} \mathrm{Kg}^{-1}$; de 5 a $24 \mathrm{~g} \mathrm{Kg}^{-1}$ para a MO; 1 a $12 \mathrm{mmol}_{\mathrm{c}} \mathrm{m}^{-3}$ para o Ca; 0 a $5 \mathrm{mmol}_{\mathrm{c}} \mathrm{dm}^{-3}$ para o $\mathrm{Mg}$; 3,6 a 4,6 para o $\mathrm{pH}$; e 6 a $87 \mathrm{mmol}_{\mathrm{c}} \mathrm{dm}^{-3}$ para a CTCe (Tabela 9).

Tabela 8. Matriz de correlação ( $r$ ) entre variáveis nas camadas $0-20-e 70-90 \mathrm{~cm}$ dos solos:

* significativo a $1 \% ;{ }^{* *}$ significativo a $5 \%$ e ns não significativo

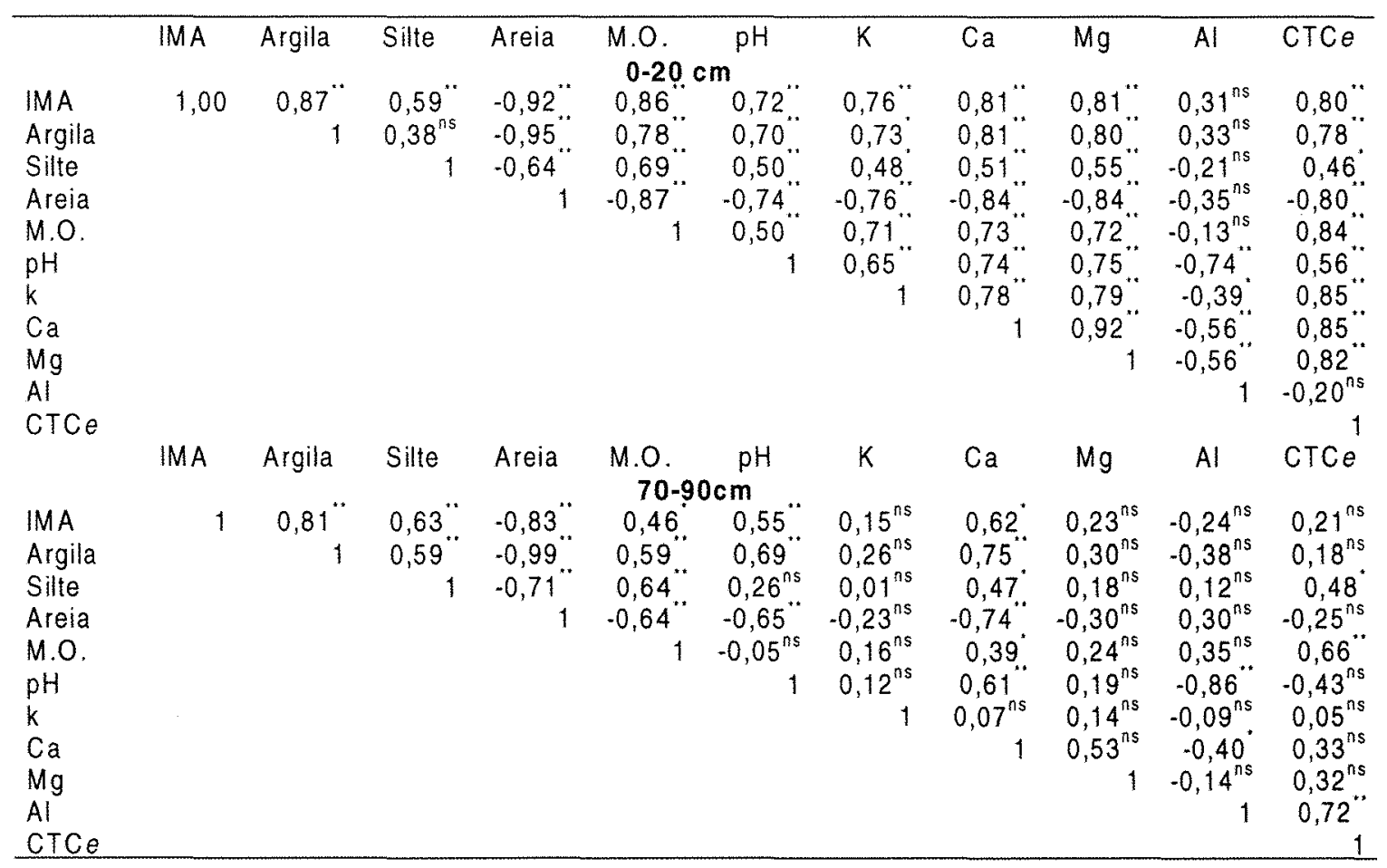


Tabela 9. Valores mínimos, máximos, médios e desvios padrões de algumas características físicas e químicas dos diferentes solos

\begin{tabular}{|c|c|c|c|c|c|c|c|c|c|c|c|}
\hline Atributo/Valor & Argila & Silte & Areia & $\begin{array}{l}\mathrm{pH} \\
\mathrm{KCl}\end{array}$ & M.O. & $P$ & $\mathrm{Ca}$ & $\mathrm{Mg}$ & $K$ & $\mathrm{Al}$ & CTCe \\
\hline & - & $\mathrm{g} \mathrm{Kg}^{-1}$ & 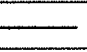 & & $\mathrm{g} \mathrm{dm}^{-3}$ & $\mathrm{mg} \mathrm{dm}^{-3}$ & - & 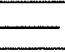 & 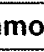 & $\mathrm{dm}^{-3}$ & \\
\hline
\end{tabular}

LVad - Latossolo Vermelho-Amarelo Distrófico Típico A Moderado Textura Média $0-20 \mathrm{~cm}$

$\begin{array}{lrrrrrrrrrrr}\text { № amostras } & 12 & 12 & 12 & 12 & 12 & 12 & 12 & 12 & 12 & 12 & 12 \\ \text { Mínimo } & 100 & 0 & 810 & 3,5 & 12 & 4 & 0 & 1 & 1 & 11 & 14 \\ \text { Média } & 121 & 21 & 840 & 3,8 & 16 & 7 & 3 & 2 & 2 & 15 & 20 \\ \text { Máxima } & 160 & 90 & 880 & 4 & 23 & 35 & 8 & 5 & 1 & 21 & 27 \\ \text { Desvio padrão } & 2 & 3 & 2 & 0,2 & 4 & 8 & 2 & 2 & 0 & 3 & 4 \\ & & & & 70-90 \mathbf{c m} & & & & & & \\ \text { № amostras } & 12 & 12 & 12 & 12 & 12 & 12 & 12 & 12 & 12 & 12 & 12 \\ \text { Mínimo } & 120 & 10 & 780 & 4,0 & 5 & 2 & 1 & 0 & 0 & 4 & 7 \\ \text { Média } & 160 & 11 & 820 & 4,0 & 7 & 3 & 1 & 2 & 0 & 8 & 11 \\ \text { Máxima } & 200 & 50 & 870 & 4,3 & 9 & 4 & 2 & 5 & 1 & 13 & 15 \\ \text { Desvio padrão } & 2 & 2 & 3 & 0,09 & 1 & 1 & 1 & 2 & 0 & 3 & 3\end{array}$

LVa - Latossolo Vermelho Distrófico Típico A Moderado Textura Argilosa e Média

$0-20 \mathrm{~cm}$

$\begin{array}{lrrrrrrrrrrr}\text { № amostras } & 21 & 21 & 21 & 21 & 21 & 21 & 21 & 21 & 21 & 21 & 21 \\ \text { Mínimo } & 0 & 10 & 660 & 3,6 & 9 & 3 & 1 & 0 & 0 & 10 & 11 \\ \text { Média } & 171 & 30 & 780 & 3,8 & 18 & 4 & 2 & 1 & 1 & 15 & 20 \\ \text { Máxima } & 280 & 40 & 860 & 4,1 & 30 & 6 & 5 & 4 & 2 & 21 & 38 \\ \text { Desvio padrāo } & & 6 & 6 & 0,1 & 6 & 1 & 1 & 1 & 0 & 3 & 5 \\ & & & & 70-90 \mathbf{c m} & & & & & & \\ \text { № amostras } & 21 & 21 & 21 & 21 & 21 & 21 & 21 & 21 & 21 & 21 & 21 \\ \text { Mínimo } & 140 & 10 & 580 & 3,6 & 5 & 2 & 1 & 0 & 0 & 6 & 6 \\ \text { Média } & 211 & 40 & 731 & 4,1 & 9 & 3 & 1 & 1 & 0 & 9 & 15 \\ \text { Máxima } & 390 & 150 & 820 & 4,3 & 24 & 6 & 2 & 1 & 1 & 22 & 87 \\ \text { Desvio padrão } & 6 & 3 & 6 & 0,2 & 4 & 1 & 1 & 1 & 0 & 4 & 17\end{array}$

LVdf - Latossolo Distroférrico Típico a Moderado Textura Argilosa

$0-20 \mathrm{~cm}$

\begin{tabular}{lrrrrrrrrrrr} 
N ${ }^{0}$ amostras & 8 & 8 & 8 & 8 & 8 & 8 & 8 & 8 & 8 & 8 & 8 \\
Mínimo & 160 & 70 & 180 & 4 & 20 & 5 & 1 & 2 & 1 & 6 & 19 \\
Média & 480 & 111 & 400 & 4,2 & 31 & 7 & 11 & 7 & 2 & 12 & 32 \\
Máxima & 650 & 180 & 770 & 4,4 & 38 & 10 & 21 & 11 & 3 & 16 & 40 \\
Desvio padrão & 15 & 4 & 18 & 0,1 & 6 & 2 & 7 & 3 & 1 & 4 & 7 \\
& & & & $70-90$ & $\mathbf{c m}$ & & & & & & \\
№ amostras & 8 & 8 & 8 & 8 & 8 & 8 & 8 & 8 & 8 & 8 & 8 \\
Mínimo & 200 & 60 & 160 & 4,1 & 9 & 2 & 1 & 0 & 0 & 2 & 7 \\
Média & 541 & 90 & 360 & 4,3 & 15 & 4 & 4 & 2 & 1 & 7 & 14 \\
Máxima & 730 & 140 & 740 & 4,6 & 19 & 5 & 12 & 4 & 1 & 14 & 20 \\
Desvio padrão & 17 & 3 & 18 & 0,2 & 4 & 1 & 4 & 1 & 0 & 5 & 6 \\
\hline
\end{tabular}


Quando associadas algumas variáveis edáficas em análises de regressão múltipla, o IMA pôde ser previsto com alta precisão $\left(R^{2} \geq 0,97\right.$ e $\left.p<0,01\right)$ (Tabela $10 \mathrm{e}$ Figura 13). As variáveis que melhor explicaram as diferenças de produtividade foram os teores de areia, $\mathrm{MO}$ e o pH (Tabela 8); sendo que areia e MO têm estreita correlação com propriedades fundamentais do solo, como a capacidade de reter água e nutrientes disponiveis, e a capacidade de aeração (Gonçalves, 2002). Assim, solos mais arenosos e pobres em matéria orgânica têm menor capacidade de fornecer água e nutrientes às árvores, resultando em menor produtividade. Isso justifica a correlação negativa IMA vs. areia $(-0,92 ; p=0,01)$ na camada $0-20 \mathrm{~cm}$ e a correlação positiva IMA vs. MO $(0,86 ; p=$ $0,01)$, na camada $0-20 \mathrm{~cm}$. Essas correlações foram menores na camada $70-90 \mathrm{~cm}$, IMA vs. areia $(-0,83 ; p=0,01)$ e IMA vs. $M O(0,46 ; p=0,05)$, porque nas camadas superiores do solo, até $30 \mathrm{~cm}$ (Gonçalves, 1994; Gonçalves \& Mello, 2000), é onde a densidade de raízes finas e a absorção de nutrientes são maiores (Barros, 1974; Gonçalves, 1990 e 1994; Carmo \& Silva, 1990), bem como há o maior aporte e variações dos teores de MO. Por sua vez, o pH correlaciona-se positivamente com os teores de bases trocáveis e com a CTCe, fatores fundamentais na nutrição das árvores. Esses resultados destacam os efeitos das características do solo de maior área, LVAd ( $49 \%$ da área total), na determinação dos índices de produtividade da E.E. de Itatinga. Por exemplo, a CTC efetiva média desse solo é de $67 \mathrm{mmol}_{\mathrm{c}} \mathrm{dm}^{3} \mathrm{e}$, a capacidade de retenção de água disponivel, cerca de $120 \mathrm{~mm}$ de água (entre 0,01 e 1,5 MPa), em $2 \mathrm{~m}$ de profundidade e, no solo LVd, a CTC efetiva média é de $14,62 \mathrm{mmol}_{\mathrm{c}} \mathrm{dm}^{-3} \mathrm{e}$, a capacidade de retenção de água disponível, cerca de $180 \mathrm{~mm}$ de água (Gonçalves, 1990; Oliveira \& Paula, 1988). Dessa forma, durante o verão, em período de estiagem, considerando uma evapotranspiração média diária de $5 \mathrm{~mm} \mathrm{dia}^{-1}$, no LVAd em 24 dias, seria consumida a água armazenada em $2 \mathrm{~m}$ de profundidade e, no LVd, 36 dias. Isso evidencia o maior potencial de deficiência hídrica do LVAd, certamente, o maior limitante de produtividade deste solo.

A ampla variação de produtividade e as variáveis independentes mais correlacionadas com a produtividade dos povoamentos de eucalipto evidenciam a variabilidade do ambiente na E.E. de Itatinga. Esses efeitos indicam que as práticas de manejo florestal devem ser distintas entre as unidades de solos. É provável que o LVAdq, 
de textura mais grossa e menos fértil, responda mais à adubação e menos ao preparo do que o LVd e LVdf.
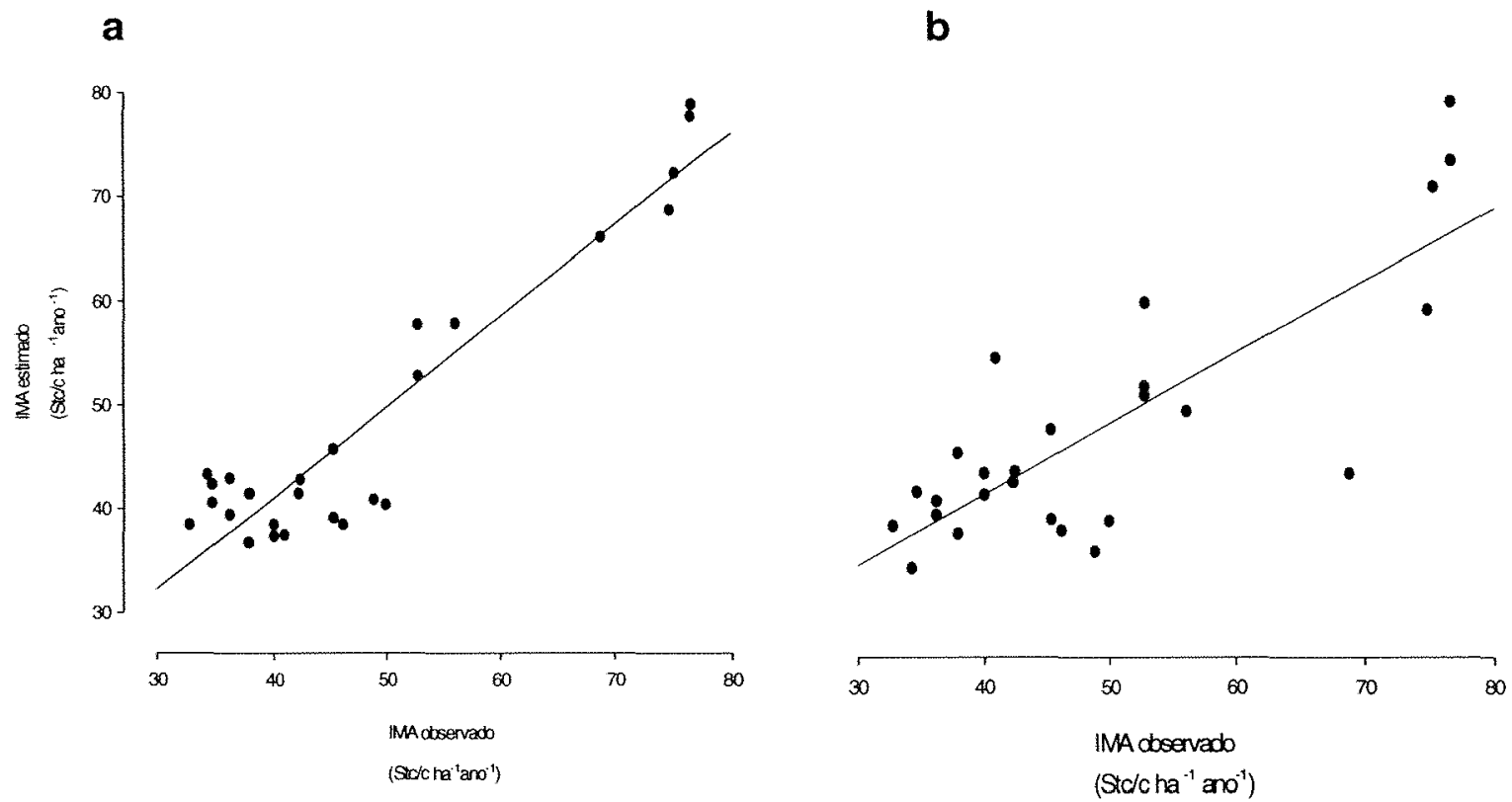

Figura 13 - Relação entre produtividade observada e estimada na camada $0-20 \mathrm{~cm}$ (a) e $70-90 \mathrm{~cm}$ (b) de profundidade.

Tabela 10. Equação de regressão múltipla relacionando o IMA com características do solo

\begin{tabular}{cccc}
\hline Profundidade & Equação $^{(1)}$ & $\mathrm{R}^{2}{ }_{\text {ajustado }}$ & $P$ \\
\hline $\mathbf{c m}$ & & $\%$ & \\
$0-20$ & $\gamma=-0,293 x_{1}+0,626 x_{2}+14,252 x_{3}$ & 99 & $<0,01$ \\
$70-90$ & $\gamma=-0,442 x_{1}+18,926 x_{4}$ & 97 & $<0,01$ \\
\hline
\end{tabular}

(1) $x_{1}=$ areia; $x_{2}=$ matéria orgânica; $x_{3}=\mathrm{pH}$ e $x_{4}=\mathrm{pH}$ 


\section{CONCLUSÕES}

1 Foram identificados dois padrões de curvas de nível na E.E. de Itatinga, um com curvas próximas, estreitas e circundantes à rede de drenagem, nas áreas mais íngremes e de menor altitude; outro, com curvas espaçadas, presentes nas áreas de maior altitude e com relevo plano e suave ondulado;

2 Foram caracterizadas cinco classes de solos, estreitamente relacionadas com os padrões fisiográficos: Latossolo Vermelho-Amarelo Distrófico típico A moderado textura média, LVAd (49\%), Latossolo Vermelho Distrófico típico A moderado textura argilosa e média, LVd, (34\%), Latossolo Vermelho Distroférrico típico A moderado textura argilosa, LVdf, (11\%), Gleissolos, G, (5\%) e Neossolo Flúvico, RU (1\%). O LVAd predomina em altitudes acima de $800 \mathrm{~m}$, em relevo suave ondulado; o LVd, entre 775 e $800 \mathrm{~m}$, em relevo ondulado; - LVdf, entre 750 e $800 \mathrm{~m}$, em áreas próximas aos canais de drenagem, em relevo ondulado; o RU, a $750 \mathrm{~m}$ e o $\mathrm{G}, 750$ e $775 \mathrm{~m}$ antecedendo os canais de drenagem;

3 Foram encontradas seis classes de produtividade nas plantações de Eucalyptus grandis: classe I, de 77 a $69 \mathrm{Stc} / \mathrm{c}$ ha ${ }^{-1}$ ano $^{-1}$, produtividade muito alta (6\%); classe II, de 68 a $62 \mathrm{Stc} / \mathrm{c} \mathrm{ha}^{-1} \mathrm{ano}^{-1}$, produtividade alta (1\% ha-1 ano1.); classe III, d ha-1 ano-1, de 61 a $54 \mathrm{ha}^{-1} \mathrm{ano}^{-1}$. Stc/c ha- $\mathrm{ano}^{-1}$, produtividade média (3\%); classe IV, de 53 a $47 \mathrm{Stc} / \mathrm{c} \mathrm{ha}^{-1} \mathrm{ano}^{-1}$, produtividade muito baixa $(10 \%)$; classe V, de 46 a $40 \mathrm{Stc} / \mathrm{c} \mathrm{ha}^{-1} \mathrm{ano}^{-1}$, produtividade muito baixa (24\%); e a classe VI, de 39 a $32 \mathrm{Stc} / \mathrm{c} \mathrm{ha}^{-1} \mathrm{ano}^{-1}$, produtividade extremamente baixa (56\%); 
4 Essas variações de produtividade apresentaram relações diretas com as características físicas e químicas dos solos. O IMA apresentou altas correlações com os teores de argila, matéria orgânica, $\mathrm{Ca}, \mathrm{Mg}$ e com o pHe a CTCe. Quando foram associadas algumas variáveis edáficas em análises de regressão múltipla, o IMA pôde ser previsto com alta precisão $\left(R^{2} 0,97\right.$ e $\left.p<0,01\right)$. Nestas análises, as variáveis que mais explicaram as diferenças de produtividade foram os teores de areia, $\mathrm{MO}$ e o $\mathrm{pH}$; e

5 Os métodos de geoprocessamento usados simplificaram, agilizaram e aumentaram a precisão dos procedimentos de espacialização e visualização das informações processadas. 


\section{REFERÊNCIAS BIBLIOGRÁFICAS}

ALVARENGA, M.I.N.; DAVIDE, A.C. Características físicas e químicas de um latossolo vermelho-escuro e a sustentabilidade de agroecossistemas. Revista Brasileira de Ciência do Solo, v.23, n. 4, p. 933-942, 1999.

ALDER, D. Estimación del volumen forestal y predicción del rendimiento: Predicción del rendimiento. Roma: FAO, 1980. v.2, 143p.

AMARAL, P.; VERRÍSSIMO, A.; BARRETO, P. et al. Plano de manejo florestal. In: AMARAL, P.; VERRISSIMO, A.; BARRETO, P. et al. Floresta para sempre: um manual para a produção de madeira da Amazônia. Belém: IMAZON, 1998. cap.1, p.2-20.

ARGENTO, M.S.F.; MARQUES, J.S. Aplicações de Sistemas de Informações em Projetos de Gerenciamento Ambiental. Geociências, n. 7, p. 21-42, 1988.

BARROS, N.F. Contribuição ao relacionamento de características pedológicas e topográficas com altura de Eucalyptus Alba na região de Santa Bárbara, MG. Viçosa, 1974. 88p. Dissertação (M. S.) - Universidade Federal de Viçosa.

BARROS, N.F.; NOVAIS. J.R.; CARDOSO, J.R; et al. Algumas relações solo-espécie de Eucalipto em suas condições naturais. In: BARROS, N.F.; NOVAIS, R.F. (Ed.). Relação solo-eucalipto. Viçosa: Ed. Folha de Viçosa, 1990. cap. 1, p. 1-24.

BERTIN, J. A neográfica e o tratamento da informação. Curitiba: UFPR, 1986. 273p. 
BENNEMA, J.; BEEK, K.J.; CAMARGO, M.N. Um sistema de classificação de capacidade de uso da terra para levantamento de reconhecimento de solos. Rio de Janeiro: DPFS/DPEA/MA/FAO, 1964. p.174.

BIGGS, P.H.; SPENCER, R.D. New approaches to extensive forest inventory in western Australia using large-scale aerial photography. Australian Forestry, v.53, n.3, p.182193, 1990.

BORATTO, J.H.T. Agenda 21: Rio-92 propostas ainda no papel. Silvicultura, v. 16, n.59, p. 6-15, jan./fev. 1995.

BECKER, G. Optimization of road network and transport systems: a pré-condition for na improved organization and design of labour in forestry. In: SEMINÁRIO DE ATUALIZAÇÃO SOBRE SISTEMAS DE COLHEITA DE MADEIRA E TRANSPORTE FLORESTAL, 8., Curitiba, 1994. Anais. Curitiba: UFPR/FUPEF, 1994. p. 111-115.

BRAGA, F.A.; BARROS, N.F.; SOUZA, A.L.; et al. Características ambientais determinantes da capacidade produtiva de sítios cultivados com eucalipto. Revista Brasileira de Ciência do Solo, v. 23, n.2, p.291-298, 1999.

BRASIL. Leis, decretos, etc. Código Florestal, lei n. 4771. Brasilia: IBDF, 1980. 39p.

BUENO, J.M.R. Modelo digital de terreno e geológico da folha 1:50 000 de Rio Claro e Itatiaia. In: CONGRESSO DE INICIAÇÃO CIENTíFICA DA UNESP, Rio Claro, 1999. Anais. Rio Claro: UNESP, 1999. 11p.

BURROUGH, P.A.; FRANK, H.V. Concepts and paradigms in spatial information: are current geographical information systems truly? International Journal of Geographical Information Systems, v.9, n.2, p. 101-116, 1995. 
CAMPO, J.C. Identificação e classificação de reflorestamentos por interpretação visual de imagens LANDSAT. Viçosa, 1982. 62p. Dissertação (M. S.) - Universidade Federal de Viçosa.

CAMPOS, S.P. Planejamento de uso do solo através do Sistema de Informações Geográficas IDRISI. Botucatu, 1996. 97p. Dissertação (M.S.) - Faculdade de Ciências Agrárias, Universidade Estadual Paulista "Júlio de Mesquita Filho".

CARMEAN, W.H. Forest site quality evaluation in the United States. Advances in Agronomy, v. 27, p. 209-269, 1975.

CARMO, D.N.; RESENDE, M.; SILVA, T.C.A. Avaliação da aptidão das terras para Eucalipto. In: BARROS, N.F.; NOVAIS, R.F. (Ed.). Relação solo-eucalipto. Viçosa: Ed. Folha de Viçosa, 1990. cap.5, p. 187-236.

CASTRO, J.F.M. Análise comparativa entre informações morfométricas obtidas por métodos convencionais e por métodos digitais. Geografia, v. 20, n. 2, p. 115-133, out. 1975.

CASTRO, J.F.M.; GERARDI, L.H.O.; BUFALO, C. Utilização de SIG na interpretação de dados dos quadros físico-natural e sócio-econômico da região administrativa de Campinas: uma proposta metodológica. Geografia, v. 2, n. 3, p. 65-93. 1998.

CINTRA, J.P. Modelos digitais de terreno. In: SIMPÓSIO BRASILEIRO DE GEOPROCESSAMENTO 1. São Paulo, 1990. Anais. São Paulo: USP, 1990. p.53-65.

COSTA, L.M. Manejo de solos em áreas florestadas. In: BARROS, N.F.; NOVAIS, R.F. (Ed.). Relação solo-eucalipto. Viçosa: Ed. Folha de Viçosa, 1990. cap.5, p.187-236.

COUTO, H.T.Z.; VETTORAZZI, C.A. A tecnologia do geoprocessamento para a Engenharia Florestal. In: SIMPÓSIO BRASILEIRO DE GEOPROCESSAMENTO, 1; São Paulo, 1991. Anais. São Paulo: USP, Escola Politécnica, 1991, p. 204-208. 
COUTO, H.T.Z. Índice de sítio: relatório interno da Champion. Mogi-Guaçu/SP: Champion Papel e Celulose, 1990.7p.

EASTMAN, R.J. IDRISI for windows user's guide version 2.0. Introduction. Worcester: Clark University, Graduate School of Geography. 1997.19p.

EMPRESA BRASILEIRA DE PESQUISA NA AGROPECUÁRIA - Centro Nacional de Pesquisas de Solos. Sistema brasileiro de classificação de solos. Brasília: EMBRAPA Produção de Informação; Rio de Janeiro: Embrapa Solos, 1999. 412 p.

ESPÍNDOLA, C.R.; GARCIA, G.J. Interpretação fotográfica de redes de drenagem em diferentes categorias de solos. Notícias Geomorfológicas, v. 18, n.35, p. 28-32, junho, 1978.

FAO. Situación de los bosques del mundo. Roma, 1997.p.53.

FAO. Trees for life. Roma, 1991. 27p.

FERREIRA, M.C. Análise integrada de dados espaciais e hidrológicos no estado de São Paulo: uma metodologia baseada em sistemas de Informação Geográfica. São Paulo, 1995.243p. Tese (Doutorado) - Faculdade de Filosofia e Ciências Humanas, Universidade de São Paulo.

FISHER, P.D.; LINDENBERG, R.E. On distinctions among Cartography, Remote Sensing, and Geographic Information Systems. Photogrammetric Engennering and Remote Sensing, v.55, n. 10, p.1431-1434. 1989

FIORIO, P.R.; TEIXEIRA, R.B.; MIRANDA, A.B. et al. Potencialidade do uso da terra na microbacia hidrográfica do córrego do ceveiro na região de Piracicaba. Scientia Agrícola, v. 56, n. 4, p. 1273-1280, out./dez. 1999. Suplemento. 
GERARDI, L.H.O.; SILVA, B.C.N. Quantificação em geografia. São Paulo: Difel, 1981. 161p.

GODDARD, R.E.; HOLLIS, C.A. The genetic basis of forest tree nutrition. In: BOWEN, G.D.; NAMBIAR, E.K.S. (Ed.). Nutrition of plantation forest, London: Academic Press. 1984. p.234-287.

GONCALVES, J.L.M. Interações genótipo-ambiente e relações entre a produtividade de sítios florestais de Eucalyptus grandis e Eucalyptus saligna com as propriedades de alguns solos de textura arenosa e média do Estado de São Paulo. Piracicaba, 1990. 135p. Tese (Doutorado) Escola Superior de Agricultura "Luiz de Queiroz", Universidade de São Paulo.

GONÇALVES, J.L.M. Características do sistema radicular de absorção do Eucalyptus grandis sob diferentes condições climáticas. Piracicaba, 1994. 90p. Tese (Livre docência) Escola Superior de Agricultura "Luiz de Queiroz", Universidade de São Paulo.

GONÇALVES, J.L.M. Principais solos usados para plantações florestais. In: GONÇALVES, J.L.M.; STAPE, J.L. (Ed.). Conservação de solos. Piracicaba: IPEF, 2002. cap. 1, p. $1-46$.

GONÇALVES, J.L.M.; MIRANDA, S.M. O sistema radicular das árvores. In: GONÇALVES, J.L.M.; BENEDETTI, V. (Ed.). Nutrição e fertilidade florestal. Piracicaba: IPEF, 2000. cap. 8. p.219-267.

HARRISON, B.A.; JUPP, D.L.P. Introduction to remotely sensed data. Canberra:CSIRO, Division of Water Resources, 1989. 141p. 
HERTZ, R.; BONETTI, J.; CASTRO, J.F.M. Potencialidade na utilização dos sistemas de informação geográfica em estudos de uso do solo e cobertura vegetal de um ambiente costeiro. Coletânea de trabalhos técnicos: CONGRESSO BRASILEIRO DE CARTOGRAFIA,15., São Paulo: Sociedade Brasileira de Cartografia, 1991. v.3, p. 587-588.

INSTITUTO DE PESQUISAS TECNOLÓGICAS DE SÃO PAULO. Mapa Geológico do Estado de São Paulo: Itapetininga/Cornélio Procópio; folha SF 22-Z-D/SF 22-Z-C. São Paulo, 1984. Escala 1:250.000.

ITO, H.K. Previsão de Erosão e demarcação de Talhões para plantação de Eucaliptos na Microbacia Hidrográfica do Rio Itupeva (São Paulo), com base num Sistema de Informação Geo-referenciada. Campinas, 1998. 88p. Dissertação (Mestrado) Faculdade de Engenharia Agrícola, Universidade Estadual de Campinas.

KALLIO, M.; DYKSTRA, D.P.; BINKLEY, C.S. The global forest sector: an analytical perpective. Chichester: John Willey, 1987. 703p.

KLEPAC, D. Crecimiento y incremento de arboles y masas forestales. Chapingo: Universidad Autonoma, 1976. 365p.

KLOCK, G.O. Determinants of soil loss tolerance. Madison: ASA, 1982. p. 53-66: Some soils erosion effects on forest soil productivity. (ASA Publication, 45)

LEÃO, R. M. A floresta e o homem. São Paulo: EDUSP, IPEF, 2000.428p.

LEMOS, R.C.; SANTOS, R.D. Manual de descrição e coleta de solo no campo. 3.ed. Campinas: Sociedade Brasileira de Ciência do Solo, 1996. 84p.

LIMA, W.P. Indicadores hidrológicos em áreas florestais. Série Técnica IPEF, v.32, n.12, p.53-64, 1998. 
LIMA, W.P. Horto Florestal de Itatinga: plano diretor. Piracicaba: ESALQ, 1989.33p.

MAFINI, G. Raster versus Vector data enconding and handling: a commentary. Photogrammetric Engineering and Remote Sensing, v. 23, n.10, p. 1379-1398, 1987.

MARTINS, A. Uso de SIG para indicação de carreadores ecológicos no município de Viçosa-MG. Revista Árvore, v.22, n. 3, p.373-380, 1999.

MONTEIRO, C.A.F. Análise rítmica em climatologia: problemas da atualidade climática em São Paulo e achegas para um programa de trabalho. São Paulo: EDUSP; Instituto de Geografia, p. 57-65, 1971.

MUMMERY, D. BATTAGLIA, M.; BEADLE, C.L.; TURNBULL, C.R.A.; MCLEOD, R. An apllication of terrain and environmental modelling in a large-scale forestry experiment. Forest Ecology and Management, v.118, n. 1/3, p. 149-159, 1999.

NILSSON, N.E. Adaptation of national and subnational forest inventories to future needs. In: WORLD FORESTRY CONGRESS, 10; Paris, 1991. Proceedings. Paris: RFF, 1991. v.4. p. 51-60.

NOVO, E.M.L.M. Sensoriamento Remoto: princípios e aplicações. São José dos Campos: INPE, 1992. 161p.

OLIVEIRA, L.B.; PAULA, J.L. Retenção e disponibilidade de água de latossolos do sudeste e sul do Brasil. In: REUNIÃO DE CLASSIFICAÇÃO, CORRELAÇÃO DE SOLOS E INTERPRETAÇÃO DE APTIDÃO AGRÍCOLA, 3. Rio de Janeiro, 1998. Anais. Rio de Janeiro: EMBRAPA, SNCLS, 1988. p.303-363. (Embrapa.SNCLS. Documentos, 12).

PERLIN, J. História das florestas: a importância da madeira no desenvolvimento da civilização. Rio de Janeiro: Imago, 1992. 490p. 
PESSOTI, J.E.S. Levantamento detalhado dos solos do Horto de Itatinga/SP. s.n.t. $105 p$.

QUIJADA, R.M. Interaccion genótipo-ambient. In: FAO. Mejora genetica de arboles forestales. Roma, 1980. p. 231-235.

REIS, M.G.F.; BARROS, N.F. Ciclagem de nutrientes em plantios de Eucalipto. In: BARROS, N.F.; NOVAIS, R.F. (Ed.). Relação solo-eucalipto. Viçosa: Ed. Folha de Viçosa, 1990. cap.7, p. 265-302.

RAMALHO FILHO, A. Sistema de avaliação da aptidão agrícola das terras. Brasília: Ministério da Agricultura; EMBRAPA, Serviço Nacional de Levantamento e Conservação de Solos, 1978. 70p.

RESENDE, M. Pedologia. Viçosa: Universidade Federal de Viçosa, 1982. 100p.

RODRIGUES, M. Geoprocessamento. São Paulo, 1987. 347p. Tese (Livre Docência)Escola Politécnica, Universidade de São Paulo.

ROY, P.S.; SINGH, I.J.; DAS, K.K.; et al. Growing stock estimation of monoculture plantation using remote sensing techniques and geographical information system - a case study in Central Tarai Forest division, U.P. Journal of proceedings, IUFRO - DNAES international meeting: resource inventory techniques to support agroforestry and environment, n. 1-3, p. 73-83, Oct. 1996.

SANTOS, A.R.; PASTORE, E.L.; AUGUSTO, F.; et al. Estradas vicinais de terra: manual técnico para conservação e recuperação. São Paulo: IPT, 1985. 140p.

SEDJO, R.A. The potencial of high-yield plantation forestry for meeting timber needs. New Forests, v. 17, n. 1/3, p. 339-359, 1999. 
SILVA, F.C. Manual de análises químicas de solo, plantas e fertilizantes. Brasília: Embrapa Comunicação para Transferência de Tecnologia, 1999. 370p.

SILVA, L.F. Solos tropicais: aspectos pedológicos, ecológicos e de manejo. São Paulo: Terra Brasilis, 1996. 137p.

SKIDMORE, A.K.; RYAN, P.J.; DAWES, W.; et al. Use of an expert system to forest soils from or geographical information system. Environmental Management, v.20, n.4, p. 553-564, 1996.

SKIDMORE, A.K.; VAREMKAMP, C.; WILSON, L.; et al. Remote sensing of soils a Eucalyptus Forest environment. International Journal of Remote Sensing, v.18, n.1, p. 39-56, 1997.

SOCIEDADE BRASILEIRA DE SILVICULTURA. Expansão competitiva do setor florestal brasileiro: Projeto PADCT III - 02 PLAT. São Paulo: SBS, ABIPTI, ABRACAVE, IPEF, IPT, CNPQ, 1998. p.

SPENCER, R.D.; GREEN, M.A. BIGGS, P.H. Integrating Eucalyptus Forest inventory and GIS in Western Australia. Photogrammetric Engineering and Remote Sensing, v.63, n.2, p. 179-181, 1997.

STAPE, J.L. Mapa de uso e ocupação do solo. Piracicaba: ESALQ, LCF, 1998. Escala 1:10.000.

STONER, E.R.; BAUMGARDNER, M.F. Characteristic variation in reflectance of surface soils. Soil Science Society of America Journal, v.45, p.1161-1165, 1981.

STURGES, H.A. The choice of a class interval. Journal of the American Statistical Association, v.21, p. 65-66, 1926. 
TAYLOR, P.J.; WALKER, G.R.; HODGSON, G.; HATTON, T.J.; CORRELL, R.J. Testing of a GIS model of Eucalyptus eargiflorens health on a semiarid, saline flood plain. Environmental Management, v. 20, n.4, p. 553-564, 1996.

THORTHWAITE, C.W.; MATHER, J.R. The water balance. Drexel: Institute of Technology, 1955. 104p.

RAIJ, B. VAN; ANDRADE, J.C.; CANTARELLA, H.; et al. Análise química para avaliação da fertilidade de solos tropicais. Campinas: Instituto Agronômico de Campinas, 2001.285p.

VELOSO, H.P. Manual técnico da vegetação brasileira. Rio de Janeiro: Ministério da Economia, Fazenda e Planejamento; Fundação Instituto Brasileiro de Geografia e Estatística; Diretoria de Geociências; Departamento de Recursos Naturais e Estudos Ambientais, 1992. 92p.

VETTORI, L; PIERANTONI, H. Análise granulométrica novo método para determinar a fração argila. Boletim Técnico Embrapa/SNLCS, n.3, p.1-8, 1968.

ZÁKIA, M.J.B. Identificação e caracterização da zona ripária em uma microbacia experimental: implicações no manejo de bacias hidrográficas e na recomposição de florestas. São Carlos, 1998. 98p. Tese (Doutorado) - Escola de Engenharia de São Carlos, Universidade de São Paulo. 